UCRL-ID-125046

\title{
An Evaluation of In-Situ Bioremediation Processes
}

\author{
Larry L. Cole \\ Mehdi Rashidi
}

\section{RECEIVED \\ SEP 201996 \\ OSTI}

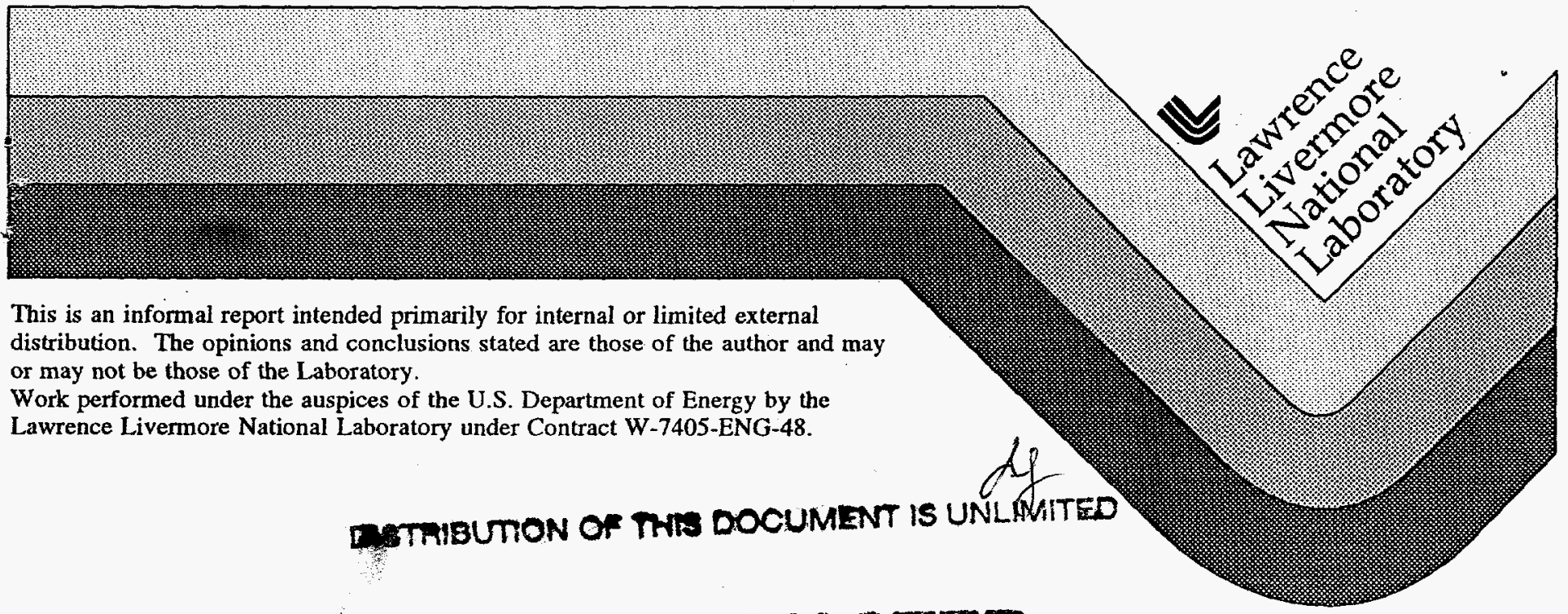




\section{DISCLAIMER}

This report was prepared as an account of work sponsored by an agency of the United States Government. Neither the United States Government nor any agency thereof, nor any of their employees, makes any warranty, express or implied, or assumes any legal liability or responsibility for the accuracy, completeness, or usefulness of any information, apparatus, product, or process disclosed, or represents that its use would not infringe privately owned rights. Reference herein to any specific commercial product, process, or service by trade name, trademark, manufacturer, or otherwise does not necessarily constitute or imply its endorsement, recommendation, or favoring by the United States Government or any agency thereof. The views and opinions of authors expressed herein do not necessarily state or reflect those of the United States Government or any agency thereof. 


\section{DISCLAIMER}

Portions of this document may be illegible electronic image products. Images are produced from the best available original document. 


\title{
AN EVALUATION OF IN-SITU BIOREMEDIATION PROCESSES
}

\author{
Larry L. Cole \\ Department of Chemistry \\ Prairie View A\&M University \\ Prairie View, TX $\mathbf{7 7 4 4 6}$

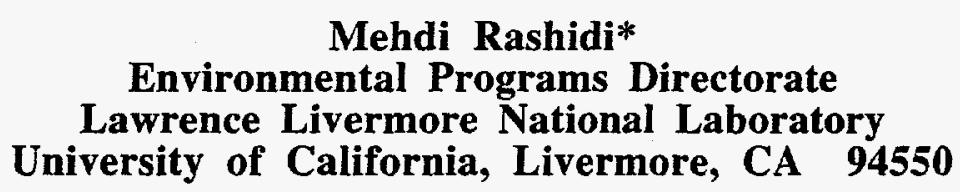

August 1996

*Author to whom correspondence should be addressed. 


\section{TABLE OF CONTENTS}

$\begin{array}{ll}\text { ABSTRACT } & 3\end{array}$

I. INTRODUCTION 4

II. APPROACHES TO ENHANCE THE RATE OF IN-SITU BIODEGRADATION 6

A. Surfactant-Enhanced Biodegradation 6

B. Enhancement of Biochemical Mechanism $\quad 8$

$\begin{array}{lr}\text { Substrate augmentation } & 8\end{array}$

Control of soil oxygen $\quad 9$

Control of soil moisture $\quad 10$

$\begin{array}{ll}\text { Nutrient augmentation } & 11\end{array}$

C. Microbial Transport $\quad 11$

$\begin{array}{ll}\text { Influence of ionic strength and } \mathrm{pH} & 11\end{array}$

Influence of microbial mobility and transport $\quad 12$

D. Augmentation of Microbes 12

E. Vegetative Uptake $\quad 14$

III. SITE POTENTIAL FOR IN-SITU BIOREMEDIATION APPLICATIONS 15

$\begin{array}{ll}\text { IV. NOVEL APPLICATIONS } & 16\end{array}$

$\begin{array}{ll}\text { V. MODELING } & 17\end{array}$

VI. ESSENTIAL EQUIPMENT 19

A. In-Situ Bioremediation Systems for Contaminated Soil Treatment 19

B. In-Situ Bioremediation Systems for Contaminated Aquifers 20

$\begin{array}{ll}\text { VII. CURRENT MAJOR PROBLEMS } & 20\end{array}$

VIII. NEEDS IN RESEARCH

IX. NEEDS IN EDUCATION 22

X. CONCLUDING REMARKS 23

$\begin{array}{ll}\text { ACKNOWLEDGEMENTS } & 23\end{array}$

$\begin{array}{ll}\text { REFERENCES } & 23\end{array}$

$\begin{array}{ll}\text { TABLES } & 32\end{array}$

$\begin{array}{ll}\text { FIGURES } & 37\end{array}$ 


\begin{abstract}
Remediation of petroleum hydrocarbons in groundwater was the primary focus in the initial application of in-situ bioremediation which, from its development in the 1970s, has grown to become one of the most promising technologies for the degradation of a wide variety of organic contaminants. The degradation of contaminants in subsurface soils is the current new focus of the technology. While the need for improvements in the technology does exist, the indisputable fact remains that this technology is by far the least expensive and that it has the capability to provide long term reduced levels of contaminants or long term complete remediation of contaminated sites. The aim of this paper is to disclose pertinent information related to current conditions and current feelings in the area of new research, novel applications, new government regulations, and an overview of new topics on the horizon that relate to the over all technology.
\end{abstract}




\section{INTRODUCTION}

The word, bioremediation, originates from two other words, namely biology and remedy. Bioremediation, therefore, is a remedy for cleaning up petroleum and other forms of contaminants by employing a biological process. The major sources of contaminants that pollute the soil and subsurface ground water are illustrated in Figure 1. Tests have proven that most of these contaminants are known or suspected carcinogens.

Groundwater is the only source for drinking water for many people around the world, especially in rural areas. In the United States groundwater supplies $42.4 \%$ of the population served by public water utilities. More than half of the population of the United States relies upon a groundwater source for drinking water (Kuzelka 1995). The most powerful and efficient process, that will bring some remedy to the mammoth amounts of hazardous wastes, that plague groundwater and soils at sites within and around many cities and communities, is best identified as a natural biological process of enzymes. Enzymes are complex proteins that are produced by living cells and are responsible for catalyzing specific biochemical reactions such as the degradation of organic contaminants. Microorganisms, mainly bacteria, use enzymes to degrade organic contaminants simply by digesting them. This process appears to be a basic characteristic of the microorganism's archeological history.

The immediate need for the remediation of contaminated groundwater and soils is apparent from the latest report of the National Research Council (1993). The report discloses that well over 400,000 sites across the nation have contaminated groundwater and will require remediation.

Biological degradation has been used over the past few decades to clean up contaminated groundwater. In-situ soil and groundwater remedial procedures, or simply in-situ bioremediation, is one of the progressive technologies for the remediation of contaminated groundwaters and subsurface soils by stimulating the microflora (habitat of microorganisms) with the addition of carbon and energy sources and trace mineral elements in place. Therefore, the contaminated system is not physically moved from its original geographical location. Total treatment occurs on site. While other on site remediation processes have been tested and examined for contaminated soils such as in-situ vitrification (Cole and Fields 1989 \& 1993), in-situ bioremediation continues to be the most economical method of remediation. The total treatment is a commercial venture, the cost of which is determined by the volume and type of contaminant at the site, the location of the contaminant in the subsurface, and the concentration of the contaminant. In-situ bioremediation is a way to manage the subsurface bioreactor to carry out biological degradations of contaminants. A successful implementation of bioremediation should include a complete aquifer characterization, removal of contaminant source and free product, plume containment, laboratory feasibility studies, installation and operation of biostimulation controls, and continuous monitoring (Alveraz-Cohen 1993). The various soil divisions where contaminants are usually found is shown in Figure 2. Typical in-situ bioremediation systems for treatment of the vadose zone and the saturated zone are 
shown in Figures 3 and 4. Since the inception of the first process in the early 70's (Raymond 1974), in-situ bioremediation has undergone many evolutionary changes in its overall procedure, general design, and range of effectiveness (Rittmann 1993, Matthews 1994, and Ritter 1995).

In general, bioremediation processes degrade organic contaminants to nontoxic and less harmful products. The degrading reaction, call oxidation-reduction, is initiated by microorganisms such as bacteria or fungi. The degradation process has the usual oxidation reaction mechanism. Typical oxidation reactions are the combustion of alkanes, such as octane $\left(\mathrm{C}_{8} \mathrm{H}_{18}\right)$. As shown below in equation (1) for the typical hydrocarbon, octane, a two mole sample of octane (228 grams), requires exactly twenty five moles of molecular oxygen (800 grams) for its quantitative oxidation to give sixteen moles of carbon dioxide ( 704 grams) and eighteen moles of water (324 grams).

$$
2 \mathrm{C}_{8} \mathrm{H}_{18}+25 \mathrm{O}_{2} \rightarrow 16 \mathrm{CO}_{2}+18 \mathrm{H}_{2} \mathrm{O}
$$

Similarly, Phenol $\left(\mathrm{C}_{6} \mathrm{H}_{6} \mathrm{O}\right)$, another common contaminant, also undergoes oxidation to give the same products as shown by equation (2).

$$
\mathrm{C}_{6} \mathrm{H}_{6} \mathrm{O}+7 \mathrm{O}_{2} \rightarrow 6 \mathrm{CO}_{2}+3 \mathrm{H}_{2} \mathrm{O}
$$

Degradation processes of hydrocarbons that require molecular oxygen (aerobic oxidation-reduction reactions) yield products of gaseous or dissolved carbon dioxide $\left(\mathrm{CO}_{2}\right)$, bicarbonate ion $\left(\mathrm{HCO}_{3}{ }^{-}\right)$, water, and new cell matter (regenerated microbes). Microorganisms that consume contaminants without the need of oxygen (anaerobic oxidation-reduction reactions) give products that may include methane gas $\left(\mathrm{CH}_{4}\right)$, nitrogen gas $\left(\mathrm{N}_{2}\right)$, hydrogen sulfide $\left(\mathrm{H}_{2} \mathrm{~S}\right)$, and reduced forms of metals such as iron $\left(\mathrm{Fe}^{2+}\right)$, and manganese $\left(\mathrm{Mn}^{2+}\right)$. For example, the anaerobic degradation of benzene $\left(\mathrm{C}_{6} \mathrm{H}_{6}\right)$ by denitrification, as shown in equation (3), gives the following products.

$$
2 \mathrm{C}_{6} \mathrm{H}_{6}+10 \mathrm{NO}_{3}^{-} \rightarrow 5 \mathrm{~N}_{2}+12 \mathrm{CO}_{2}+6 \mathrm{H}_{2} \mathrm{O}
$$

Microbial degradation (also referred to as microbial transformation) of organic and some inorganic contaminants takes place because the microorganisms can use the contaminants for their own growth and reproduction. Bacteria, the microorganisms focused on in this paper, go through phylogeny in the kingdom called Monera and belong to the class, Schizomycetes. Bacteria are classified as microscopic plants because earlier taxonomists found that they had a rigid cell wall. These cellular microscopic plants range from 0.5 to $35.0 \mu \mathrm{m}$ in length or diameter depending on their shape. Figure 5 shows a comparison of the bacteria size with the sizes of some commonly occurring microscopic particulates. Bacteria have round, rod like, spiral, or filamentous shaped 
bodies (Figure 6). They are considered single celled (or noncellular bodies) and often aggregate into colonies. They are either motile by means of flagella, or nonmotile. Bacteria live in soil, water, organic matter, or the bodies of plants and animals. Figure 7 shows a comparison of microscopic images of sperms, yeast cells, coccus bacteria, and bacillus bacteria. Some of the characteristics of typical bacteria active in contaminant remediation are gathered from various sources and are listed in an alphabetical order in Table I. Table I provides important data for researchers on bacterium's type, size, living environment, fluorescence capability, and references for further information.

Microorganisms responsible for biological degradation of contaminants have rates of reaction that are extremely sensitive to a number of different conditions, such as temperature, $\mathrm{pH}$, oxygen, and nutrients (Rittmann 1993, Matthews 1994, and Ritter 1995). The most favorable conditions for bacteria feeding and digestion are $\mathrm{pH}$ values between 6.0 and 10.0, temperatures ranges of 25 ${ }^{\circ} \mathrm{C}$ to $35^{\circ} \mathrm{C}$ and a ratio of organic carbon to nitrogen and phosphorus of 300:15:1.

Nutrient requirements are based on a number of different variables. In most cases, the contaminated region has the required amount of nutrients essential for the growth and maintenance of the desired bacteria. This of course represents the ideal scenario, called intrinsic or natural bioremediation, where the contaminated region has sufficient indigenous microbes, nutrients, and required oxygen or other electron acceptors for the natural biodegradation of contaminants.

\section{APPROACHES TO ENHANCE THE RATE OF IN-SITU BIODEGRADATION}

\section{A. Surfactant-Enhanced Biodegradation}

One of the major difficulties often encountered in the persistence of potentially biodegradable contaminants in the environment is their nonavailability to the microflora. Occasionally, the microorganisms themselves may be capable of producing a surfactant which enhances the solubility of the contaminants, and this alone may suffice for obtaining sufficient quantities in an available form (Ying et al. 1989). Surfactants are a general class of chemicals whose molecular structure generally consist of a hydrophobic group (water hating) and a hydrophilic group (water loving). Surfactants are usually used to enhance the effectiveness of in-situ treatment processes by improving both the detergency of aqueous solutions applied to subsurface soil and the efficiency with which organics may be transported by aqueous solutions from the subsurface to the surface. For example, by preferentially wetting the solid surface, an aqueous solution can partially or completely displace an adsorbed organic fraction. The preferential wetting ability by the solution is the result of the surfactant's detergency action that decreases the interfacial tension between the aqueous phase and the solid phase. This in turn makes the contaminant available for microorganism consumption. Research is being conducted to optimize the geochemical aspects of surfactant-enhanced subsurface remediation (Edwards et al. 1991, Rouse et al. 1993, Pennel et al. 1993, Shiau et al. 1994, and Sabatini et al. 1995). 
Sanseverino et al. (1994) have performed batch equilibrium tests on coke waste solids to determine which surfactants would promote bioremediation of the known contaminant, $\left[{ }^{14} \mathrm{C}\right]-$ phenanthrene. The results showed that each of five surfactants studied could solubilize $\left[{ }^{14} \mathrm{C}\right]-$ phenanthrene from the waste material. The extent of solubilization as a function of concentration varied. Table II gives the results of the nonionic surfactants studied. Surfactant, Tween 85, showed the best solubilization characteristics in the lower dose range, where 0.2 percent solubilized 6.1 percent of the $\left[{ }^{14} \mathrm{C}\right]$-phenanthrene. In general, a minimum of 0.2-0.5 percent surfactant was required to begin solubilizing the contaminant from the coke waste.

The surfactants, Alfonic 180-60 and Novel II 1412-56 (Vista Chemical Company, Austin Texas) were reported to increase the desorption of phenanthrene from soil and, at concentrations of $10 \mu \mathrm{g} / \mathrm{g}$ soil, increase the extent of biodegradation of phenanthrene (Aronstein, et al. 1991). Results of studies on Tween 85 (Sigma Chemical Company, St. Louis, Missouri) have suggested that this surfactant may modify the rate of hydrocarbon solubilization and therefore promote microbial oil degradation (Lupton and Marshall, 1979). The enhance microbial degradation of decane with the application of the surfactant, Neodol 23-3/23-9 (Shell Chemical Company, Houston, Texas) has also been reported by Bury and Miller (1991).

Surfactant-enhanced subsurface remediation has proven to be an effective tool for in-place treatment systems. However, according to a report by Krebbs-Yuill et al. (1995), the process is not economically feasible without a means for surfactant-contaminant separation and surfactant reuse. The recycling of surfactants was the major focus of a study by Lipe et al. (1996). This research evaluated micellar-enhanced ultrafiltration (MEUF) along with air stripping for surfactantcontaminant separation and surfactant recovery. The objectives of the research were: (1) to evaluate critical factors affecting the performance of MEUF and air stripping processes for surfactantcontaminant separation and surfactant recovery and reuse in groundwater remediation efforts, and (2) to modify existing design equations to incorporate these effects and to validate these models against experimental data. Micellar-enhanced ultrafiltration (MEUF) refers to the increased ability of ultrafiltration membranes to remove surfactants and contaminants from a waste stream due to the colloid-sized surfactant micelle. The micellar contaminant and surfactant are therefore retained by the ultrafilter while surfactant monomer and aqueous (extra-micellar) contaminant pass through the membrane.

The results of their study revealed that MEUF effectively concentrated the surfactantcontaminant system ( 93 to 99 percent retention) into a reduced volume, but surfactant-contaminant separation did not occur. Optimization of the process involves consideration of the contaminant type as well as careful surfactant selection. An economic analysis specific to each application will be necessary to identify the optimum combination of surfactant selection, unit process, and treatment train order for the integrated surfactant-enhanced subsurface remediation process. 


\section{B. Enhancement of Biochemical Mechanism Substrate augmentation}

Very often, microbes have the ability to degrade a contaminant even though the contaminant can not serve as the primary energy source for the organisms. The growth and maintenance of the microbes is supported by the presence of other compounds called primary substrates (Wilson and Wilson 1985). Similar conditions of multiple substrates and cosubstrates and a consortia of microbes exist in contaminated soil systems. These may create an environment where chemicals are degraded that are otherwise resistant to degradation in single-chemical-single-species assays (Keck et al. 1989). Cooxidation and cometabolism are two terms that have been used to identify the degradation of a recalcitrant substrate when and only when a growth producing substrate is also present.

Cooxidation of contaminants is a condition where recalcitrant hydrocarbons are oxidized when present as cosubstrates in a medium in which one or more different hydrocarbons are added for bacterial growth (Foster 1962a \& 1962b). Several researcher have identified cooxidation for the degradation of recalcitrant hydrocarbons (Horvath 1972, McKenna 1976, Perry 1979, and Sims \& Overcash 1983).

Cometabolism of contaminants is a transformation where an enzyme of a microorganism, growing on a compound, recognizes another compound as a substrate and transforms it to a product. This transformation is limited, because the next enzyme of the organism that should attack in sequence, has a higher specificity and does not recognize the new product as a substrate. For pure cultures, cometabolism is not effective. For mixed cultures, the initial cometabolic transformation could provide subsequent attacks by other organisms (Atlas \& Bartha 1980).

The addition of auxiliary carbon and energy sources (substrates) to a contaminated area is often necessary to stimulate the microflora to initiate the biodegradation of recalcitrant contaminants such as carbon tetrachloride (DiStefano et al. 1991, Doong \& Wu 1992, and Gibson \& Sewell 1992). Experimental results show that the rate of microbial activity can be enhanced by the addition of different primary substrates. For example, significant rate enhancements of carbon tetrachloride degradation were observed with the supplement of different substrates to the microbial community under anaerobic conditions (Doong 1995). While all substrates enhanced the degradation rates, optimum rate enhancements were observed from the addition of acetate, relative to glucose and humic acid. Ferrous ion $\left(\mathrm{Fe}^{2+}\right)$ was the reducing agent and nitrate ion $\left(\mathrm{NO}_{3}^{-}\right)$was supplied as the electron acceptor.

Aerobic in-situ biotransformation of chlorinated aliphatic hydrocarbons with phenol and toluene as primary substrates has also been reported by Hopkins \& McCarty (1995). In a simulated test representing a groundwater travel time of less than 2 days, removal efficiencies for $250 \mu \mathrm{g} / \mathrm{L}$ of trichloroethylene and $125 \mu \mathrm{g} / \mathrm{L}$ of cis-1,2-dichloroethylene were greater than $90 \%$, and that of $125 \mu \mathrm{g} / \mathrm{L}$ trans-1,2-dichloroethylene was about $74 \%$, when either $9 \mathrm{mg} / \mathrm{L}$ toluene or $12.5 \mathrm{mg} / \mathrm{L}$ 
phenol was used. The substrates, phenol and toluene, were removed to below $1 \mu \mathrm{g} / \mathrm{L}$. Vinyl chloride was removed to greater than $90 \%$. Both hydrogen peroxide and pure oxygen had the same efficiencies as the required electron acceptors in these experiments.

Additional information has also been reported on the effects of substrates (acetates, methanol, and some short-chain organic acids and alcohols) on the dechlorination of polychlorinated biphenyls (Nies \& Vogel 1990), 2,4,5-trichlorinated biphenyl (Gibson \& Suflita 1990), chloroanilines (Kuhn, et. al. 1990), and tetrachloroethlyene (Fateherpure \& Boyd 1988, Bagley \& Gossett 1990, and Gibson \& Sewell 1992). These findings show great improvements in the consumption of contaminants by bacteria as a result of multisubstrate use.

\section{Control of soil oxygen}

Anaerobic (without oxygen) biodegradation processes are orders of magnitude slower than aerobic (with oxygen) biodegradation processes and are much more difficult to accelerate, optimize, and control (Carberry 1994). For example, the microbial degradation of chlorinated aromatic hydrocarbons was investigated by several researchers. Zacharias et al. (1995) have reported on the aerobic and anaerobic biodegradation of a mixture of chlorinated aromatic hydrocarbons. The experiment used semi-scale plants which served as models for a contaminated industrial site (concept of slow sand filters). The plants consisted of columns filled with contaminated soil from the industrial site. Containers of the actual contaminated water from the site were also used. Biodegradation by a natural biocoenose of microorganisms was demonstrated using either pure oxygen, air, or nitrogen. The operating parameters for each of the four pilot plants are shown in Table III. After 110 days, in all aerated columns more than $99 \%$ of chlorobenzenes, $96 \%$ of the chlorophenols, and $94 \%$ of the absorbable halogens were degraded. In comparison, respectively only $82 \%, 78 \%$, and $49 \%$ of these compounds were degraded in the nitrogen-supplied column. Clearly, the rates of degradation are much faster in the aerated columns (aerobic biodegradation) relative to rates in the nitrogen-supplied columns (anaerobic biodegradation). Furthermore, the total bacteria cell counts of water and soil were approximately ten times higher in the aerated columns compared to the anaerobic or sandfilled columns. Microbial activity measured as respiration in the fixed beds showed the same profile. Other studies of microbial aerobic degradation of chlorinated aromatic hydrocarbons have been reported in the literature, but most of these studies have been done on a laboratory bench scale. For example, Menke and Rehm (1992) investigated biodegradation of phenol and monochlorophenols in laboratory test systems, Haigler et al. (1992) and Sander et al. (1991) isolated and described bacteria degrading of several chlorinated benzenes. Biodegradation pathways of the halogenated aromatic hydrocarbons are reviewed by Chaudhry and Chapalamadugu (1991). These investigations all indicate that rates of biodegradation are oxygen dependent. 
Air sparging is currently being used with excellent success to control oxygen in bioremediation (Figure 8). Air is injected into the groundwater to remove volatile chemicals and deliver oxygen, which promotes microbial growth. Bioventing, a somewhat similar process, circulates air through the subsurface to bring about similar results as air sparging. Volatile contaminants are removed and the circulating oxygen stimulates microorganisms to degrade remaining contaminants. Bioventing has, likewise, proven to be quite successful and is, according to many researchers in the field, the hottest commercially used item today in bioremediation technology.

\section{Control of soil moisture}

The influence of soil moisture on microbial activity has been reported by several different researchers (Hilling 1976, Ying et al 1989, and Kulshrestha 1992). A specific case study showed that pendimethalin [N-(1-ethylproply)-3,4-dimethyl-2,6-dinitroaniline] was biodegraded by microorganisms at a much faster rate in test samples containing $92 \%$ water relative to those containing 22\% water (Kulshrestha 1992).

Moisture optimization is demonstrated in experiments that measured carbon mineralization (degradation) at different moisture levels for soil containing 15,000 ppm oil and 35,000 ppm oil (Ying et al, 1989). The results indicated a peak in microbial activity at a $15 \%$ moisture content (TableIV). These studies show that contaminant biodegradation becomes the highest for a soil moisture content of about $15 \%$. Furthermore, they show that increasing the soil moisture content above $15 \%$ would actually decrease the biodegradation of the contaminant.

\section{Nutrient augmentation}

Nutrient requirements are not easy to predict for a given contaminated site. Nutrients already exist at the site in the subsurface materials, the groundwater, the indigenous bacteria as fixed nitrogen, and from dead bacteria (Norris 1994). However, specific nutrients are sometimes required to be supplied to a contaminated area in in-situ bioremediation systems (see Figures 3, 4, and 8). Samples of the contaminated regions usually undergo laboratory studies to verify that indigenous organisms are present to degrade the contaminants that are present. From these laboratory tests, the optimum nutrient levels are also determined.

Laboratory tests must consider if the site is aerobic (oxygen rich) or anaerobic (oxygen free). Most hydrocarbon contaminants such as benzene, toluene and other alkylbenzenes are readily degradable in aerobic (oxygen rich) surface water and soil systems (Gibson \& Subramanian 1984 and Ridgway et al. 1990). Contamination by organic compounds in the subsurface environment, however, results in the total consumption of available oxygen by indigenous microorganisms which results in the development of anaerobic (oxygen free) conditions. Yeh and Novak (1994) have demonstrated the type of in-depth study usually performed to identify the specific nutrient 
requirements for an anaerobic specific contaminated site. Their study evaluated the biodegradation of methyl tertiary butyl ether (MTBE), ethyl tertiary butyl ether (ETBE), and tertiary butyl alcohol (TBA) - three chemicals used as gasoline additives. The anaerobic biodegradation under sulfate reducing, methanogenic and denitrifying conditions were measured in static soil and water microcosms using soils of different origin and varying characteristics. Potassium nitrate $\left(\mathrm{KNO}_{3}\right)$ and potassium sulfate $\left(\mathrm{K}_{2} \mathrm{SO}_{4}\right)$ were added to stimulate denitrification and sulfate reduction, respectively. The specific objectives of their study were to evaluate the biodegradation potential of TBA, MTBE, and ETBE in soils previously uncontaminated with fuels; study the effect of site variation on degradation; and determine the environmental factors that influence TBA, MTBE, and ETBE biodegradation. The inorganic nutrient amendment consisted of $\mathrm{KH}_{2} \mathrm{PO}_{4}, \mathrm{Na}_{2} \mathrm{HPO}_{4}$, $\mathrm{NH}_{4} \mathrm{Cl}$, and mineral solution ( $\mathrm{NaCl}, \mathrm{CaCl}_{2}, \mathrm{MgCl}_{2}+6 \mathrm{H}_{2} \mathrm{O}$ ). The results indicated that TBA was the easiest compound to biodegrade, whereas MTBE was the most recalcitrant. With nutrient addition, TBA degradation increased to the same level in soils from all sites under both denitrifying and methanogenic conditions. Degradation of MTBE and ETBE occurred only in the soil with the lowest organic matter content. The addition of nutrients had very little effect on increasing the biodegradation of MTBE and ETBE in organic-rich soils. Therefore, the degradation of MTBE and ETBE are expected to be difficult in a groundwater system contaminated by fuels.

In general, metal salts such as ammonium sulfate, disodium phosphate, monosodium phosphate, sodium carbonate, magnesium sulfate and ferrous sulfate are typical ingredients that may exist in nutrient mixtures (Ritter and Scarborough 1995). The essential nutrients of nitrogen and phosphorus, are stoichiometrically related to the amount of contaminant present. Three pounds of oxygen are approximately required to convert one pound of hydrocarbon mass to carbon dioxide and water. The nutrient requirements based on the mass of hydrocarbon to be consumed are approximated by a ratio of carbon to nitrogen to phosphorus of 100:10:1 (Norris 1994). Other ratios of carbon to nitrogen to phosphorus have been reported to be 120:10:1 and 300:15:1 by Sims et al. (1990) and Ritter \& Scarborough (1995), respectively.

\section{Microbial Transport}

\section{Influence of ionic strength and $\mathrm{pH}$}

Microbial transport can have an extreme influence on the rate of contaminant degradation. For a microorganism to be useful for in-situ bioremediation it must be readily transported from the point of application to the zone of contamination. A large number of studies have therefore focused attention on bacteria transport in porous media. Jewett et al. (1995) have reported on the influence of ionic strength and $\mathrm{pH}$ on the transport of the bacterium, Pseudomonas Fluorescens P17. Their experiments were performed in porous media using continuous-flow laboratory columns and a rapid screening technique in which radio labeled cells were applied to large-pore, glass-fiber filters.

They used colloid-filtration theory developed from the one-dimensional filtration equation (Yao et 
al. 1971) to interpret P17 transport results in the two systems. The ionic strength of the carrying solution had a direct relation to the retention time of the bacteria and to the value, $\alpha$, the collision efficiency. The collision efficiency, $\alpha$, is the ratio of the number of bacteria removed by the collector to the number of bacteria-collector collisions, or the probability that a collision results in an attachment. Therefore, as the value of $\alpha$ decreases, the retention time decreases, and bacterial transport increases. Decreasing the ionic strength (based on ionic concentration) from $10^{-1}$ to $10^{-5}$ $M$ (where, $M$ is the molarity) caused the bacteria collision efficiency to decrease about $90 \%$ (from 0.18 to 0.026 in screening experiments and from 0.12 to 0.015 in column experiments) as a result increasing their transport (see Table V). Bacteria transport, however, was unaffected by changes in $\mathrm{pH}$ in the range of $5.5<\mathrm{pH}<7.0$ in both systems (see Table $\mathrm{V}$ ). The influence of ionic strength on transport parameters of other microorganisms have also been reported by Hilbert (1992), Logan et al. (1993), and Kinoshita et al. (1993) with results similar to the findings of Jewett et al (1995). Values of bacteria collision efficiencies, $\alpha$, have been calculated for Pseudomonas aeruginosa with a glass surface by Martin et al. (1991). Value of $\alpha$ has also been estimated on 40-mm glass beads using radiolabeled $P$. fluorescens $P 17$ by Gross et al. (1995). The bacterial collision efficiency values, $\alpha$ 's, reported by these investigators are in direct agreement with the results of Jewett et al. (1995).

\section{Influence of microbial motility on transport}

It has been shown that bacterial motility facilitates advective transport through natural aquifer sediments by changing the attachment-detachment kinetics to reduce retardation. The studies by Bales et al. (1995) showed that the time scale of attachment was twice as long for bacteria at $4{ }^{\circ} \mathrm{C}$, a temperature at which they were not motile, than for the same bacteria at $18{ }^{\circ} \mathrm{C}$, a temperature at which they were motile. Attachment was reversible at both temperatures. Their results suggest that motility enhances transport of bacteria, even in a system that is dominated by advection. Analysis of complete breakthrough curves using a nonsteady, kinetically limited, transport model suggested that motile bacteria traveled twice as far as nonmotile bacteria before becoming attached to sediment grains. Once attached to the soil particles, nonmotile bacteria detached on a time scale of 9-17 days versus $4-5$ days for the motile bacteria.

\section{Augmentation of Microbes}

In-situ bioremediation is concerned with stimulating the indigenous subsurface microflora to degrade the contaminants in place, although in some cases genetically engineered microbes with specialized metabolic activity have also been used. Given sufficient time and proper physical and chemical conditions, most organic and some inorganic compounds can be degraded biologically (Bandyopadhyay 1994). Two basic methods are currently used for the procurement of the Microorganisms necessary to initiate bioremediation. 
1. Bioaugmentation, which involves the inoculation of adapted and genetically coded toxicantdegrading microorganisms (Figure 9).

2. Biostimulation, which involves the inoculation of the necessary nutrients to stimulate the growth of indigenous microorganisms.

Microorganisms are able to survive for prolong periods of time in a dormant stage in the soil system, much like a wild bear during long winter months. They are, however, able to grow and function when favorable nutritional and environmental conditions occur. In some contaminated sites, the required microorganisms that are specific degraders for the contaminants that are present, may not be available. This was the condition at the site in Conroe, Texas, where EPA and Rice University personnel used microorganisms in a disposal pit contaminated with creosote compounds to degrade five of these compounds (Bandyopadhyay 1994).

Burns et al. (1995) have investigated bacterial strains capable of biodegrading atrazine and simazine in surface water. The bacteria (SL1: Rhodococcus rhodochrous and WT1: Acinetobacter junii) were inoculated into pilot-scale fixed beds of granular activated carbon (GAC, $1 \mathrm{~m}$ depth, 15 min empty bed contact time). The results showed that inoculation of GAC with bacterial species SL1 reduced the build up of atrazine and simazine adsorbed to GAC over the six month study. Indigenous WT1 and laboratory-produced WT1 biodegraded the bacteria to the same extent in a simple batch test. Therefore, to increase biodegradation (and reduce adsorbed and eluted SL1) inoculation must load significantly larger numbers of WT1 on the GAC relative to naturally occurring numbers of indigenous WT1. Other studies of microbial inoculation have been reported. Biodegradation of s-triazine was increased to $53 \%$ atrazine and $58 \%$ simazine in 20 days at $15^{\circ} \mathrm{C}$ by inoculation of fixed bed granular activated carbon with s-triazine-degrading bacteria with influent concentration of $10 \mu \mathrm{g} \mathrm{L}$ of both s-triazine (Feakin et al. 1995). Inoculation of granular activated carbon fixed beds to increase biodegradation was also reported to be successful at laboratory scale (Speitel et al. 1989). Inoculation may not be successful, however, in full-scale granular activated carbon beds due to displacement and wash out following competition with indigenous species (Ramadan et al. 1990) or due to operational parameters such as backwashing and flow rate (Servais et al. 1991)

The rates of biodegradation of benzene, toluene, and xylene by indigenous microorganisms in a natural aquifer sand were investigated by Corseuil and Weber (1994). The results of this study confirmed that sufficiently large populations of indigenous organisms were capable of degrading the targeted contaminants in short periods of time under favorable growth conditions and in the presence of adequate amounts of oxygen. The results also confirmed that the low population of microorganisms, typically present in subsurface systems, may require the augmentation of those microbes to prevent the significant delays, observed in their study, before onset of measurable biodegradation even under highly favorable oxygen and nutrient conditions. Such delays were found to vary inversely with the number of contaminant-specific microorganisms initially present 
in the indigenous consortia, suggesting the need for attainment of critical biomass concentrations. Critical biomass concentrations here means sufficiently large enough to ensure good survival in the presence of competition from indigenous bacteria. The overall research results strongly suggest that attention should be given to the potential need for augmentation of indigenous microbial populations to increase rates of contaminant bioremediation (Corseuil and Weber 1994). Other observations of success and failure with respect to inoculation of microbes having specific metabolic capabilities have also been reported by Lehtomaki \& Niemela (1975), Edgwehill \& Finn (1983), Crawford \& Mohn (1985), Aamand et al. (1989), and Oldenhuis et al. (1989).

\section{E. Vegetative Uptake}

This review has focused on microorganisms as the major contaminant destroyer of toxic organic chemicals. However, well-defined contaminated sites containing high concentrations of toxic organics may require intervention with sophisticated and costly soil cleaning or water filtering equipment. This is done in order to quickly mitigate human exposure and prevent additional environmental damage. Once energetic remediation techniques have initially reduced contaminant sources, less expensive approaches are then employed to minimize the financial burden of the longterm remediation processes. Usually microbes are used for the long-term treatment. However, plants have been considered and have shown to be a promising approach for in-situ bioremediation of the rhizosphene by Lee and Banks (1993), and Radwan et al. (1995).

While plants have not been studied extensively for bioremediation, they possess the tremendous potential for facilitating contaminant removal and destruction. Many of the same enzymes found in animals and microorganisms are also found in plants. Plant enzymes have been found to be responsible for the metabolic deactivation of herbicides and the detoxification of fungal pathogens. Plants also have additional contaminant inhibiting capabilities not found in microbes. Plants have extensive root systems that are ideal for absorbing both organic and inorganic contaminants. The roots contribute to the symbiotic growth of bacteria and fungi in the upper regions of the unsaturated zone (rhizosphere), which both enhances the health of the plant and increases the population of the contaminant-consuming microorganisms (see Figure 2). The results is a duel operation of both plants and microorganisms, working together, as an in-situ bioremediation system.

Donaldson and Luster (1991) have reported on the accumulating evidence indicating that there is a multiplicity of cytochrome P-450 enzymes in plants. These enzymes have been implicated in the metabolic degradation of sterols, terpenes, gibberellins, and xenobiotics. Their results show that cytochromes P-450 enzymes are involved in the detoxification (degradation) of certain herbicides.

Plant species can be selected to extract and assimilate, or extract and chemically decompose, target contaminants through phytoremediation (Nyer and Gatliff 1996). Many inorganic chemicals 
considered environmental contaminants to humans are, in fact, vital nutrients to plants that can be absorbed through the plant's root system for use in growth and development. Heavy metals can be taken up and bioaccumulated in plant tissues. Organic chemicals, notably pesticides, can be absorbed and metabolized by plants, including trees.

\section{SITE POTENTIAL FOR IN-SITU BIOREMEDIATION APPLICATIONS}

The determination of the nature and extent of the contamination at a site involves a complete and through understanding of the focused area both in terms of the natural state of the site and the contamination problem. Some of the factors that are important with regard to the natural state of the site are listed below.

- Site hydrogeology should be examined and thoroughly understood. The rate of remediation of petroleum hydrocarbons is usually always controlled by the rate of the distribution of oxygen and nutrients. Therefore aquifer hydrogeological properties such as the rate of groundwater recirculation are critical. A 24-hour pump test and groundwater flow models are helpful in site hydrogeology studies.

- Other potential contaminants that are not biodegraded, such as heavy metals, should be identified. A combination of several remedial technologies may be required for such a site.

- Conditions that affect bacteria growth and metabolism at a given contaminated site must be taken into account when in-situ bioremediation plans are being considered. Lang \& Viedt (1994) have shown that microbial activity is critically hampered at in-situ sites (macro- or micro-) with phenolic chlorinated hydrocarbon concentrations of about 30 micromole per liter or higher in the soil solution. At sites contaminated with a mixture of nonphenolic and phenolic chlorohydrocarbons, the dissolved concentration of the phenolic compounds can be critical for the biodegradation of all chlorohydrocarbons. Specific test can be made to determine the extent of microbial population support.

The following factors should be considered when evaluating the nature and extent of the contamination at a potential site.

- The concentration of contaminants on aquifer solids is extremely important, especially for petroleum hydrocarbons with low or poor solubilities.

- The presence and extent of oily phase materials should be carefully determined. Pretreatment to remove such heavy contamination may be required before in-situ bioremediation should be applied.

The method used to determine the potential for bioremediation at a specific site relies heavily on the results of modeling techniques. It has become the common practice to conduct aquifer tests and apply computer models to evaluate the feasibility of bioremediation at a particular site (Rafai and Bedient 1987). The applications of models will be discussed more later in another section. 


\section{NOVEL APPLICATIONS}

In-pore transport processes in homogeneous and heterogeneous porous media have been investigated using novel 3D imaging techniques at our laboratories (Rashidi \& Milanovich 1994, Rashidi 1995, Rashidi \& Rinker 1996, Rashidi \& Dickenson 1996, Rashidi et al. 1996a, Rashidi et al. 1996b, Rashidi 1996). The experimental setup consists of a clear column packed with clear particles and a refractive index-matched fluid seeded with fluorescent tracer microparticles (for flow measurements), an organic dye (for contaminant concentration measurements), or fluorescently stained bacteria (for bacteria concentration measurements). As shown in Figure 10, the column is illustrated by an Argon-ion laser sheet and a CCD camera is used to record the experimental runs.

The refractive index-matching yields a transparent porous medium, free from any scattering and refraction at the solid-liquid interfaces, thus allowing direct optical probing at various vertical planes within the porous system. The system is automated to image through the porous medium for collecting microscopic values of velocity, concentration, and grain geometry at high accuracy and high resolution. Various geometric, flow, and transport quantities have been obtained in a full three-dimensional volume within the porous medium.

Figure 11 shows the distributions of microscopic velocity, concentration, and flux for $t=30$ minute into an experimental run at several corresponding cross-sections in the column. As seen here, contaminant transport can be visualized and analyzed at a very high resolution and accuracy. These plots show that the contaminant zone moves faster through the higher porosity regions. It is also observed that near the contaminant front the microscopic velocities and concentrations are highly correlated. In other words, the high velocity regions are seen to be correlated with the regions of high chemical concentration and vice versa. Furthermore, it is observed that there is no such a thing as uniform flow/transport front within the porous regions. Due to the complexity of pore structure, contaminant transport becomes very complex phenomenon. As early as minute 30 , one can observe saturated regions at the end of the test section while the average contaminant front is half way in the test section. These 3D microscopic plots provide an unprecedented insight to the problem of contaminant migration and bioremediation in natural porous media.

These results show the importance of micro-scale observations and measurements in understanding of contaminant migration in soil or other natural porous media. These experimental tools are extremely valuable in bioremediation problems since microscopic particle-contaminantbacterium interactions are the key to understanding and optimization of these processes.

In another unique approach, an in-situ microbial filter technology has been developed for remediating subsurface groundwater contaminated with trichloroethylene (Taylor et al 1993, Knapp et al. 1995, and Taylor \& Hanna 1995). This new technology eliminates problems associated with the common method of directly pumping a quantity of nutrients into the subsurface to stimulate growth of indigenous microbes. Direct injection of nutrient stimulation packages not only results in the displacement of the soluble contaminants, but also does not selectively 
encourage the growth of the most efficient microbial degraders. These problems are circumvented with the application of the 2-dimensional in situ microbial filter strategy (Taylor \& Hanna 1995).

The process design is based on the use of nondividing (resting-state) cells, Methylosinus trichosporium $\mathrm{OB} 3 \mathrm{~b}$, that are produced in bioreactors, harvested, resuspended in a buffer or clean groundwater, and then injected underground to form an attached biocatalytic filter (i.e., injected microbes attach to the soil and form a fixed-bed biofilter). The potential feasibility and effectiveness of an attached resting-cell filter strategy over extended periods of time has been demonstrated for degrading tirchloroethene flowing through a saturated homogeneous quartz sand (Oklahoma) by Taylor et al. (1993), Shonnard et al (1994), Hanna \& Taylor (1995), and Knapp et al (1995). This special method of allowing contaminants to flow through resting state microbial filters is, therefore, a great benefit in the technology. The problem of displacement of contaminants and microbes usually results when volumes of microbes are directly injected into the contaminated site. This displacement problem does not occur in the in-situ microbial filter technology.

In addition, Wilson (1995) and Neal (1995) have shown that zero-valent metals, in particular iron, are capable of environmental remediation using oxidation-reduction reactions on chlorohydrocarbons. It appears that toxic trichloroethene undergoes biodegradation in the presence of metal iron filings. The contaminated groundwater of a manufacturing plant in Sunnyvale, California, has been completely remediated of toxic trichloroethene by exploiting two hundred twenty tons of zero-valent iron filings buried underground (Wilson 1995). The general reaction of a chlorinated solvent, such as trichloroethene, and a pure metal, such as iron, results in the reduction of the solvent (RX to $\mathrm{RH}$ ) and the oxidation of the metal iron (Fe to $\mathrm{Fe}(\mathrm{II})$ ).

$$
\mathrm{Fe}^{0}+\mathrm{RX}+\mathrm{H}^{+} \rightarrow \mathrm{Fe}^{2+}+\mathrm{RH}+\mathrm{X}^{-}
$$

The technical procedure at the Sunnyvale site involved placing permeable underground barriers containing an iron and sand mixture. Contaminated groundwater seeps through at a rate of one foot per hour. Researchers have reported that the rate of degradation increases with increasing ratio of iron surface area to solution volume. The metal iron does dissolve during the remediation process but scientists have concluded that the disappearance is so slow that the constructed remediation barriers will remain effective for decades (Wilson 1995).

Other studies have shown that while iron is an excellent degrader for many chlorinated aliphatics, it nevertheless, has little effect on such compounds as polychlorinated biphenyls (PCBs) which are serious environmental contaminants.

\section{MODELING}

Bioremediation modeling or more commonly referred to as groundwater contamination modeling grew out of the need to predict the fate of contaminants flowing in groundwater moving 
streams. Models provide a basic structure of ideas for a systematic ordered arrangement of information about contaminated sites. Model users develop complete and total awareness of the contaminant behavior because they are required to confront and understand details such as the mass of contaminants, their chemical properties, and their interactions with site hydrogeochemical characteristics.

Basic modeling strategies have evolved over the years for a number of possible contamination scenarios. Physical, chemical, and biological postulates are currently being used to construct bioremediation models. The actual development of a model begins with the step of translating or describing a real physical problem in terms of mathematical equations that capture the total, critical aspects of the real problem. When the required information is available and is correctly integrated into the proper model, modeling predictions become useful tools for managing field sites and evaluating bioremediation.

The actual mixing of contaminants with selected bacteria can be a major problem that affects the rate of degradation. Consequently, high microbial mobility is advantageous, since the success of remediation procedures depends on the ability to transfer bacteria to the contaminated area. Therefore, the rate of mass transport in porous media has been and continues to be the focus of attention in a number of publications ranging from the results of actual experiments to the development of numerical models. The aim is to gain better understanding and insight to problems related to colloidal transport in porous media (Rashidi et al. 1996a \& b).

Modern groundwater contamination models are multicomponent models. Modeling has proven to be the cure to the problem of quantifying biodegradation in the subsurface. Models combine physical, chemical, and biological processes to supply quantitative information concerning microbial kinetics, contaminant and microbial transport, instantaneous reactions, and a number of other interactions related to bioremediation. A full and comprehensive discussion of models has been reported by the National Research Council (1990).

Transport problems have been challenging and have focused on such complex systems as layered aquifer or fractured medium. Tang and Aral (1992a) have reported on the analytical solutions describing the fate of a solute in a layered aquifer system. In a second paper by Tang and Aral (1992b), the analytical solutions are utilized in solution of several problems to demonstrate the range of problems that may be analyzed using their procedure. They have described the limitations and the general description of the mathematical model utilized in the analysis and its analytical solution.

Prediction of field scale contaminant transport in the vadose (unsaturated) zone is essential for the management of potentially hazardous chemicals in the ecosystem. This information is valuable in developing methods to minimize the pollution of the drainage water in underlying groundwater supplies. Russo (1995a) has derived closed-form analytical expressions for the longitudinal and transverse components of the velocity variance and for the asymptotic values of 
the transverse components of the displacement covariance for saturated flow and transport. The applicability of this approach for modeling flow and transport in the vadose zone (unsaturated zone) is then tested (Russo 1995b) by the use of the stochastic theory of Yeh et al. (1985a \& b) for unsaturated flow. Results of these analyses strongly suggest that this model may predict flow and transport in vadose regions if heterogeneity scale in the mean flow direction is smaller than about a tenth of the characteristic length scale of unsaturated flow (Russo 1995b).

Jennings and Manocha (1994) provide a more historical perspective and explore the state of the art in modeling soil bioremediation under saturated flow conditions. The application of the models under unsaturated conditions is also discussed in their article. Hu and Brusseau (1995) have examined the effect of solute size on transport in structured porous media. The dual-porosity mobile-immobile model was used to attempt to quantify the solute size effect. Solutes examined were pentafluorobenzoate, 2,4-dichlorophenoxyacetic acid, hydroxypropyl-B-cyclodextrin, and tritiated water $\left({ }^{3} \mathrm{H}_{2} 0\right)$. The experimental breakthrough curves obtained in the aggregated and stratified media were compared to the predicted curves simulated with the first-order, dual-porosity mobile-immobile transport model. In most cases, the predicted simulations matched the experimental data quite well. The results of the work demonstrated that the dual-porosity mobileimmobile model can be used to approximate solute transport in aggregated and stratified media, at least for systems similar to those in the study.

The potential significance of sedimentation as a mechanism for bacterial transport has also been examined by Wan et al. (1995). A simple model was developed to predict the behavior of particle (bacterial or inorganic colloids) sedimenting through granular porous media under hydrostatic conditions. Their experimental results demonstrated that sedimentation within pore waters may be an important mechanism for downward transport of bacteria in groundwater.

\section{ESSENTIAL EQUIPMENTS}

\section{A. In-Situ Bioremediation Systems for Contaminated Soil Treatment}

The components required for in-situ bioremediation of contaminated soil generally include delivery systems (to supply water, nutrients, oxygen, inorganic and organic matter, and specialized microorganisms) and run-on and run-off controls (for moisture control and waste containment) (U.S. EPA 1984 \& 1990). Table VI discloses some ranges of critical environmental conditions that affect aerobic and anaerobic activity of soil microorganisms . Equipment required to control and modify these conditions usually is part of the equipment package.

The major problems in the application of in-situ bioremediation to unsaturated subsurface soils is the delivery of required nutrients, cooxidation-oxidation substrates, electron acceptors or other necessary enhancers of microbial growth. It appears that gravity and forced hydraulic delivery and venting systems are the techniques presently used for the delivery. Other approaches 
such as hydraulic fracturing, radial drilling and cyclic pumping are still in the development stage (Sims et al. 1993).

\section{B. In-Situ Bioremediation Systems for Contaminated Aquifers}

In-situ bioremediation systems for aquifers usually consist of injection wells, galleries, and/or trenches and also recovery wells as shown in Figure 3 (Norris 1994). The most common design provides treatment of recovered groundwater, typically using an air stripper tower. The recovered treated groundwater is amended with nutrients and is re-injected. Usually oxygen or hydrogen peroxide are added by injection in the injection well. The common design can be modified to introduce oxygen by air sparging (Figure 8 ) or by bioventing, both of which introduces air directly within the aquifer.

Nutrients can be added a number of different methods. In the case of shallow aquifers, for example, with sandy material, nutrients can be introduced from the surface, allowing percolation of rain water or added water to carry the supply of nutrients into the aquifer.

Most groundwater recirculation systems have designs that are best done by employing a groundwater flow model. A two-dimensional analytical flow model will be sufficient for most contaminated sites. The most favorable design concept can be selected and evaluated by the model.

Monitoring wells should be incorporated in the general design of an in-situ bioremediation system. Monitoring wells are essential to the continuous day-to-day functions of the system. Important information such as oxygen and nutrients distributions, $\mathrm{pH}$ and other groundwater chemistry parameters, groundwater elevations, and changes in contaminant concentrations are provided by monitoring wells. Figures 4,8 and 9 show the process of in-situ bioremediation with added systems for addition of required materials.

\section{CURRENT MAJOR PROBLEMS}

One of the major problems in bioremediation is the lack of ability to quantitatively evaluate the technology. Its benefits can not be realized unless it is clearly evaluated and shown that these processes do actually work. Therefore, there is an essential need to observe microscopic interactions, measure the pore-scale quantities, and analyze the overall processes systematically (see Rashidi et al. 1996a \& b). Rittmann et al. (1993) suggest more research and education to improve the ability to evaluate bioremediation technologies. They provide a three-part strategy for proving that bioremediation has worked in the field.

Similarly, Alvarez-Cohen (1993) reports that the biggest challenges associated with the application and managing a subsurface bioreactor for in-situ bioremediation are evaluating its progress in the field and determining when sufficient contaminant destruction has occurred to warrant discontinuation of the biostimulation.

Hutter and Vandegrift (1992) have suggested that the major limitation of in-situ bioremediation technologies concerns the inability to transport sufficient oxygen and nutrients to 
the subsurface contaminants which is required for the maintenance of biological activity. The problem of transport of sufficient oxygen, however, has been circumvented with the application of bioventing. Bioventing supplies large quantities of oxygen directly to contaminated site thereby insuring the degradative activity of microorganisms.

\section{NEEDS IN RESEARCH}

The following represents needs for additional or continued research cited directly from recent literature related to in-situ bioremediation.

- There is a need for a database on kinetic parameters of biodegradation. Information on biodegradation kinetics is essential in the design of bioremediation treatment systems and during the process of establishing limits on the release of organic contaminants to the environment.

- More pilot scale experiments are required for the microbial degradation of chlorinated aromatic hydrocarbons.

- Parameters are greatly needed for the quantitative modeling of transport of microorganisms in porous media that would establish functional relationships between surface characteristics of the media and cell transport, and of other solids in the media and cell transport.

- An improvement in the method for the inoculation of microorganisms with regard to better determination of the optimum inoculum density requirement; the required contact time between the bacteria and the target compound (contaminant or substrate) for complete or even partial mineralization.

- Protocols need to be developed for the evaluation of in-situ bioremediation. The protocols should focus on a range of contaminants and site characteristics.

- Mathematical models should be improved and also developed to give better understanding to chemical, physical, and biological phenomena.

- Improved technical methods of monitoring the degradation progress in the field are required.

- Research to improve site characterization techniques is required.

- Improved methods for quantifying metabolic activity and cellular constituents in microbes are required.

- There is a need to replace mono-species toxicity tests with ecologically oriented tests which consider bioconcentration, tropic interactions, and varied endpoints. New biomonitoring techniques should be developed based upon existing knowledge of thermodynamics, statistical mechanics, ecology, hydraulics, and information theory.

- Methods to increase rates of in-situ bioremediation of dense nonaqueous phase liquids (DNAPLs) are needed. Research should focus on quantitative bench-scale studies of methods to increase the bioavailability of contaminants (use of surfactants, or biosurfactants) to directly increase rates of biodegradation of DNAPLs. 
- Research should be conducted on biostimulation and bioaugmentation for the remediation of mixtures of chlorinated solvents. The work should be on quantitative bench-scale studies addressing the mixtures of chlorinated solvents, primarily pentachloroethane, trichlorioethene and carbontetrachloride. The expected outcome of this research is an increased understanding of biodegradation rates and efficiency, and better control of in-situ bioremediation processes for the destruction of mixed chlorinated solvents.

- Biotreatment technologies for toxic inorganics and radionuclides should include quantitative bench-scale studies of concepts for mobilization, concentration and subsequent recovery of toxic elements and radionuclides in the subsurface, which can not be readily removed by groundwater pumping or soil washing.

- Rapid methods to detect in-situ biodegradation products should be developed and used for determination of the performance and extent of bioremediation and fate of contaminants.

- Last but most importantly, a series of detailed microscopic experiments should be performed on observation, measurement, and analysis of contaminants-site particles-bacteria interactions. These experiments will answer many questions and unknowns that exist about the processes of in-situ bioremediation as never done before.

\section{NEEDS IN EDUCATION}

There is a strong necessity for developing educational programs to prepare people who will work on bioremediation projects. Academics, students, and practitioners should be directly involved in the debate concerning the preparation of students to work in bioremediation (Grady 1994).

Because bioremediation is multidisciplinary, the focus of the program should be on those students with undergraduate degrees in environmental engineering, chemical engineering, geohydrology, microbiology, and soil science.

In addition, all components of society should be educated about what bioremediation is and what its capabilities and limitations are. The following needs in education should be placed in focus and means of establishing a method of implementation should be considered.

- Training courses are required that selectively extend the knowledge bases of the technical personnel involved with the application of in-situ bioremediation.

- Training courses and educational programs are required to formally educate the next generation of technical personnel.

- Communications should be improved between all directly and indirectly involved in the technology.

- The Department of Energy's education mission of Environmental Management (EM) should be implemented in order to achieve its goals with a strong focus on bioremediation. 


\section{CONCLUDING REMARKS}

In-situ bioremediation processes have been described in light of recent applications. It has been shown that although a great deal is known about these processes, there is still an essential need for more research and education in this field.

Research should be directed such that there are more systematic interactions of laboratory, field, and modeling investigations. Detail laboratory experiments should be conducted on microscopic and macroscopic observation and measurement of contaminant-bacterium-soil interactions. These studies should compliment field measurements and modeling developments. New sensors are needed for detail, dynamic, multicomponent measurements of subsurface parameters. New micro and macromodels are also needed for numerical simulations of subsurface processes.

Education should be provided to scientists and technicians by academic institutions and government agencies (e.g., EPA, DOE, and DoD) in the form of courses, conferences, and data/case documentations. This should be done to improve scientific interactions and collaborations among the investigators.

As a result of these improvements, we will not only answer the crucial questions related to the complex problem of in-situ bioremediation, but also solve some significant general problems in the field of sensors, transport, biology, medicine, and numerical simulations.

\section{ACKNOWLEDGEMENTS}

This work was conducted under the auspices of the U. S. Department of Energy by Lawrence Livermore National Laboratory under the LDRD program and the Science and Engineering Alliance program. The authors would also like to thank graduate students, Andrew Karanja and Eric Dickenson, for their assistance in this research.

\section{REFERENCES}

Aamand J., C. Jorgensen, E. Arvin, and B. Jensen, "Microbial Adaptation to Degradation of Hydrocarbons in Polluted and Unpolluted Groundwater", Journal of Contaminated Hydrology 4 299-312 (1989) .

Alvarez-Cohen, L., "Engineering Challenges of Implementing In Situ Bioremediation", In Situ Bioremediation; When Does It Work?, Editors: Kenneth M. Reese and Barbara A. Bolding, 136152 (1993).

Aronstein, B., Y.M. Calvillo, and M. Alexander, "Effects of Surfactants at Low Concentrations on the Desorption and Biodegradation of Sorbed Aromatic Compounds in Soil", Environmental Science Technology 25, 1728-1731 (1991).

Atlas R. M. and R. Bartha, Microbial Ecology: Fundamentals and Applications, Addison-Wesley, Reading, Mass. (1980).

Bagley, D., and J.M. Gossett, "Tetrachloroethene Transformation to Trichloroethene and cis-1,2Dichloroethene by Sulfate-Reducing Enrichment Cultures", Applied Environmental Microbiology 56, 2511-2516 (1990). 
Bales, R.C., S.M. Li, K.M. Maguire and M.T. Yahya, "Virus and Bacteria Transport in a Sandy Aquifer, Cape Cod, MA", Ground Water 33, 653-661 (1995).

Bandyopadhyay, S., S.K. Bhattacharya, and P. Majumdar, "Engineering Aspects of Bioremediation", Remediation of Hazardous Waste Contaminated Soils, Editors: Donald L.Wise and Debra J. Trantolo, Marcel Dekker, Inc., 55-75 (1994).

Benton, M. J., M. L. Malott, S. S. Knight, C. M. Copper, and W. H. Benson, "Influence of sediment composition on apparent toxicity in a Solid-Phase Test using Bioluminescent Bacteria", Environmental Toxicology and Chemistry 14(3), 411-414 (1995).

Birkeland, S. E., L. Stepaniak, and T. Sorhaug, "Quantitative Studies of Heat-Stable Proteinase from Pseudomonas fluorescens P1 by the Enzyme-Linked Immunosorbent Assay", Applied and Environmental microbiology 49, 382-387 (1985).

Buchanan, R. E., and N. E. Gibbons, Bergey's Manual of Determinative Bacteriology, 8th Edition (1974).

Burns R.G., S.J. Feakin, B. Gubbings, I. McGhee, and L. Shaw, "Inoculation of Granular Activated Carbon with s-Triazine-Degrading Bacteria for Water Treatment at Pilot-Scale", Water Research 29(7), 1681-1688 (1995).

Bury, S.J. and C.A. Miller, "Effect of Micellar Solubilization on Biodegradation Rates of Hydrocarbons", 65th Colloid and Surface Science Symposium, American Chemical Society, University of Oklahoma, Norman, OK, June 17-19 (1991).

Carberry, J.B., "Bioremediation of Hydrocarbon-Contaminated Soils Using Indigenous Microbes", Remediation of Hazardous Waste Contaminated Soils, Editors: Donald L. Wise and Debra J. Trantolo, Marcel Dekker, Inc., 317-162 (1994).

Chaudhry, G.R., and S. Chapalamadugu, "Biodegradation of Halogenated Organic Compounds", Microbiology Review 55, 59-79 (1991).

Cole, L.L. and D.E. Fields, "Techniques of Radium Remediation", ORNYCF-93/75, Oak Ridge National Laboratory, Oak Ridge Tennessee (1993).

Cole, L.L. and D.E. Fields, "In-Situ Vitrification: A Review", ORNLTM-11293, Oak Ridge National Laboratory (1989).

Corseuil, H.X. and W.J. Weber Jr., "Potential Biomass Limitations on Rates of Degradation of Monoaromatic Hydrocarbons by Indigenous Microbes in Subsurface Soils", Water Resources Research 28(6), 1415-1423 (1994).

Crawford, R.C. and W.W. Mohn, "Removal of Pentachlorophenol from Soil Using a Flavobacterium." Enzyme Microbial Technology 7, 617-620 (1985)

DiStefano, T.D., J.M. Gossett, and S.H. Zinder, "Reductive Dechlorination of High Concentrations of Tetrachloroethene to Ethene by an Anaerobic Enrichment Culture in the Absence of Methanogenesis", Applied Environmental Microbiology 57(8), 2287-2292 (1991).

Donaldson, R.P. and D.G. Luster, "Multiple Forms of Plant Cytochromes P-450", Plant Physiology 96, 669-674 (1991).

Doong, R, and S. C. Wu, "Enhanced Biodegradation of Carbon Tetrachloride by the Supplement of Substrate and Mineral I Anaerobic Condition", Water Environment Research, (67) (3), 276-281 (1995).

Doong, R. and S.C. Wu., "The Effect of Oxidation-Reduction Potential on the Biotransformations of Chlorinated Hydrocarbons",Water Science Technology (G.B.) 26(1-2), 159-168 (1992). 
Duba, A. G., K. J. Jackson, M. C. Jovanovich, R. B. Knapp, and R. T. Taylor, "TCE Remediation Using In-Situ Resting-State Bioaugmentation", Environmental Science and Technology 30, 1982-1989 (1996).

Edgehill R.U. and R.K. Finn, "Microbial Treatment of Soil to Remove Pentachlorophenol", Applied and Environmental Microbiology 45, 1122-1125 (1983)

Edwards, D.A., R.G. Luthy, and Z. Liu., "Solubilization of Polycylic Aromatic Hydrocarbons in Micellar Nonionic Surfactant Solutions", Environmental Science and Technology 25, 127-133 (1991).

Fatherpure, B.Z. and S.A. Boyd, "Dependence of Tetrachloroethlyene Dechlorination on Methanogenic Substrate Consumption by Methanosarcina sp. Strain DCM", Applied Environmental Microbiology 54(12), 2976-2980 (1988).

Feakin, S. J., E. Blackburn, and R. G. Burns, "Inoculation of Granular Activated Carbon in a Fixed Bed with s-Triazine-degrading Bacteria as a Water Treatment Process", Water Research 29, 819-825 (1995).

Foster, J. W., "Hydrocarbon as Substrates for Microorganisms", Antonie van Leeuwenhoek J. Microbiol. Serol. 28, 241-274 (1962a)

Foster, J. W., "Bacteria Oxidation of Hydrocarbons" In Oxygenases, Edited by O. Hayaishi, Academic Press, New York (1962b).

Gannon, J. T.,V. B. Manilal, and M. Alexander, "Relationship between Cell Surface Properties and Transport of Bacteria through Soil", Applied and Environmental Microbiology 57, 190-193 (1991)

Gannon, J., Y.Tan, P. Baveye, and M. Alexander, "Effect of Sodium Chloride on Transport of bacteria in a Saturated Aquifer Material", Applied and Environmental Microbiology 57, 2497-2501 (1991).

Gibson, D.T. and V. Subramanian, "Microbial Degradation of Organic Compounds", Editor: D.T. Gibson, Marcel Dekker, Inc., New York, 181-252 (1984).

Gibson, S.A. and G.W. Sewell, "Stimulation of Reductive Dechlorination of Tetrachloroethene in Anaerobic Aquifer Microcosms by Addition of Short-Chain Organic or Alcohols", Applied Environmental Microbiology 58(4), 1393-1393 (1992).

Gibson, S.A. and J.M. Suflita, "Anaerobic Biodegradation of 2,4,5-Trichlorophenoxyacetic Acid in Samples from a Methanogenic Aquifer: Stimulation by Short-Chain Organic Acids and Alcohols", Applied Environmental Microbiology 56(6), 1825-1832 (1990)

Grady, C.P.L., "Bioremediation Education", Water Environment Research 66(2), 99-99 (1994).

Gross M.J., O. Albinger, D.G. Jewett, B.E. Logan, R.C. Bales, and R.F. Arnold, "Measurement of Bacterial Collision Efficiencies in Porous Media", Water Research 29, 1151-1158 (1995).

Haigler B.E., C.A. Pettigrew, and J.C. pain, "Biodegradation of Mixtures of Substituted Benzenes by Pseudomonas sp. Strain JS150", Applied.Environmental Microbiology 58, 22372244 (1992).

Hanna, M.L. and R.T. Taylor, "Attachment/Detachment and Trichloroethylene Degradation by Resting Cells of Methylosinus Trichosporium OB3b.", Abstracts of the 95th General Meeting of the American Society for Microbiology, Washington, D.C., May 21-25, p. 413 (1995).

Harvey, R.W., "Parameters Involved in Modeling Movement of Bacteria in Groundwater", in Modeling the Environmental Fate of Microorganisms", edited by C.J. Hurst, 89-114, American Society for Microbiology, Washington, D.C. (1991). 
Hilbert T.A. "Bacterial Attachment in Porous Media", M.S. thesis, University of Arizona, Tucson, Arizona (1992).

Helling, C.S., "Dinitroaniline Herbicides", Journal of Environmental Quality 3, 1-15 (1976).

Hopkins, G.D. and P.L. McCarty, "Field Evaluation of In Situ Aerobic Cometabolism of Trichloroethylene and Three Dichloroethlyene Isomers Using Phenol and Toluene as the Primary Substrates", Environmental Science \& Technology 29, 1628-1637 (1995).

Horvath, R.S., "Microbial Co-Metabolism and the Degradation of Organic Compounds in Nature", Bacteria Review 36, 146-155 (1972).

Hu, Q., and M. L. Brusseau, "Effect of Solute Size on Transport in Structured Porous Media", Water Resources Research 31(7) 1637-1646 (1995).

Hussain, R., B. Menz, H. M. Dockrell, and T. J. Chiang, "Recognition of Mycobacterium leprae recombinant $18000 \mathrm{MW}$ epitopes by Igo subclasses in Leprosy", Immunology 84, 290-297 (1995).

Jang, L. K., P. W. Chang, J. E. Findley, and T. F. Yen, "Selection of Bacteria with Favorable Transport properties Though Porous Rock for the Application of Microbial-Enhaned Oil Recovery", Applied and Environmental Microbiology 46, 1066-1072 (1983).

Jennings, A.A., and A. Manocha, "Modeling Soil Bioremediation", In Remediation of Hazardous Waste Contaminated Soils, edited by Donald L. Wise and Debra J. Trantolo, pp 645-680, Marcel Dekker, Inc, New York (1994).

Jewett, D.G., T.A. Hilbert, B.E. Logan, and R.G. Arnold, "Bacterial Transport in Laboratory Columns and Filters-Influence of Ionic Strength and pH on Collision Efficiency", Water Research 29 (7), 1673-1680 (1995).

Keck, J., R.C. Sims, M. Coover, and K. Park, "Evidence for Cooxidation of Polynuclear Aromatic Hydrocarbons in Soils", Water Research 23 (12), 1467-1476 (1989).

Joklik, W. K., H. P. Willett, D. B. Amos, and C. M. Wilfert, Zinsser Microbiology 20th Edition (1992).

Kalish, P. J., J. A. Stewart, W. F. Rogers, E. O. Bennett, "The Effect of Bacteria on Sandstone Permeability", Journal of Petroleum Technology, July, 805-814 (1964).

Kinoshita T., R.C. Bales, M.T. Yahya, and C.P. Gerba, "Bacteria Transport in a Porous Medium: Retention of Bacillus and Pseudomonas on Silica Surfaces", Water Research 27, 1295-1301 (1993).

Knapp, R.B., R.T. Taylor, M.L. Hanna, and D.R. Shonnard, "Mathematical Description for the Attachment of Resting-State Cells to a Quarts Sand", Abstracts of In Situ and On Site Bioreclamation: The Third International Symposium. San Diego, CA, April 24-27, Battelle Press, Columbus, OH (1995).

Krebbs-Yuill, B., J.H. Harwell, D.A. Sabatini, and R.C. Knox. "Economic Considerations in Surfactant-enhanced Pump-and-Treat Remediation", In Surfactant-enhanced Subsurface Remediation: Emerging Technologies, ed. D.A. Sabatini, R.C. Knox, and J.H. Harwell, ACS Symposium Series 594, Washington, D.C., American Chemical Society (1995).

Kuhn, E.P., G.T. Townsend, and J.M. Suflita, "Effect of Sulfate and Organic Carbon Supplements on the Reductive Dehalogenation of Chloroanilines in Anaerobic Aquifer Slurries", Applied Environmental Microbiology 56, 2630-2637 (1990). 
Kulshrestha, G. and S.B. Singh, "Influence of Soil Moisture and Microbial Activity on Pendimethalin Degradation", Bullitine of Environmental Contaminant Toxicology 48, 269-274 (1992).

Kuzelka, B., "Communities Stand Guard Over Groundwater", Water Environment \& Technology 7(4), 24-24. (1995).

Lang, E. and H. Viedt, "Degradation by and Toxicity to Bacteria of Chlorinated Phenols and Benzenes, and Hexachlorocyclohexane Isomers", Microbial Ecology 28, 53-65 (1994).

Laskin, A. I., and H. A. Lechevalier, CRC Press Hand Book of Microbiology 2nd Edition (1977).

Lee, E. and M. K. Banks, "Bioremediation of Petroleum Contaminated Soil Using Vegetation", Journal of Environmental Science and Health. A28, 2187-2198 (1993).

Lehtomaki, M. and S. Niemela, "Improving Microbial Degradation of Oil in Soil", Ambio 4, 126 129 (1975).

Lin, J., I. O. Lee, J. Frey, J. L. Slonczewski, and J. W. Foster, "Comparative Analysis of Extreme Acid Survival in Salmonella typhimurium, Shigella flexneri, and escherichia coli", Journal of Bacteriology 177, 4097-4104 (1995).

Lipe, K.M., D.A. Sabaniti, M.A. Haesgawa, and J.H. Harwell, "Micellar-enhanced Ultrafiltration and Air Stripping for Surfactant-Contaminant Separation and Surfactant Reuse", Ground Water Monitoring \& Remediation 16(1) 85-92 (1996).

Logan B.E., T.A. Hilbert, and R.G. Arnold R.G., "Removal of Bacteria in Laboratory Filters: Models and Experiments", Water Research 27, 955-962 (1993).

Lupton, F.S. and K.C. Marshall, "Effectiveness of Surfactants in the Microbial Degradation of Oil", Geomicrobiology J. 1, 235-247 (1979).

Macleod, F. A., H. M. Lappin-Scott, and J. W. Costerton, "Plugging of a Model rock System by Using Starved Bacteria", Applied and Environmental Microbiology 54, 1365-1372 (1988).

Madsen, E. L., and M. Alexander, "Transport of Rhizobium and Pseudomonas through Soil", Soil Science Society American Journal 46, 557-560 (1982).

Martin, R.E., L.M. Hanna, and E.J. Bouwer, "Determination of Bacteria Collision Efficiencies in a Rotating Disk System", Environmental Science \& Technology 25, 2075-2082 (1991).

Matthews, J.E., T.M. Vogel, J.M. Thomas, M. Reinhard, P.L. McCarty, C.H. Ward, R.C. Bordon, J.T. Wilson, L. Sergorin, E.J. Bouwer, D.H. Kampbell, R. Brown, R.E. Hinchee, and, R.D. Morris, Handbook of Bioremediation, Lewis Publishers, an imprint of CRC Press (1994).

McCaulou, D.R. and R.C. Bales, "Effect of Temperature-Controlled Motility on Transport of Bacteria and Microspheres Through Saturated Sediment", Water Resources Research 31(2), 271280 (1995).

McKenna, E.J., "Biodegradation of Polynuclear Aromatic Hydrocarbon Pollutants by Soil and Water Microorganisms", WRC Research Report No 113, University of Illionois, Water Research Center, Urbana, IL (1976).

Menke, B. and H.J. Rehm H.J., "Degradation of Mixtures of Monochlorophenols and Phenol as Substrates for Free and Immobilized Cells of Alcaligenes sp. A7-2.", Applied Microbiology \& Biotechnology 37, 655-661 (1992). 
Mueller, J. G., P. J. Chapman, B. O. Blattmann, and P. H. Pritchard, "Isolation and characterization of a Fluoranthene- Utilizing Strian of Pseudomonas pauscimobilis", Applied and Environmental Microbiology 56, 1079-1086 (1990).

National Research Council, Ground Water Models: Scientific and Regulatory Applications, Washington, D. C., National Academy Press (1990).

National Research Council, In Situ Bioremediation. When Does It work?, National Academy Press, Washington, D.C. (1993).

Neal, L.K., "Bimetallic Process Quickly Eliminates Contaminants", Water Environment \& Technology 7(6), 20-20 (1995).

Nies, L. and T.M. Vogel, "Effects of Organic Substrates on the Dechlorination of Aroclor 1242 in Anaerobic Sediments", Applied Environmental Microbiology 56(9), 2612-2618 (1990).

Norris, R.D., "In-Situ Bioremediation of Soils and Ground Water Contaminated with Petroleum Hydrocarbons", Handbook of Bioremediation, edited by John E. Matthews, 17-37, Lewis Publishers, Boca Raton (1994).

Oldenhuis, R. K., L. Kuiijk, A. Lammer, D. B. Janssen, and B. Withold, "Degradation of Chlorinated and Non-chlorinated Aromatic Solvents in Soil Suspensions by Pure Bacterial Cultures", Applied Microbiology and Biotechnology 30, 211-217 (1989).

Overcash, M. R. and D. Pal, "Design of Land Treatment Systems for Industrial Waste-Theory and Practice", Ann Arbor Science, Ann Arbor (1979).

Palumbo, A.V., S.P. Scarborough, S.M. Pfiffner, and T.J. Phelps, "Influence of Nitrogen and Phosphorus on the In-Situ Bioremediation of Trichloroethylene", Applied Biochemistry and Biotechnology 51/52, Spring, 635- 647 (1995).

Pennel, K.D., L.M. Abriola, and W.J. Weber, "Surfactant-enhanced Solubilization of Residual Dodecane in Soil Columns, I: Experimental Investigation", Environmental Science and Technology 27(12), 2332-2340 (1993).

Perry, G.T., J.K. Volkman, and R.B. Johns, "Fatty Acids of Bacterial Origin in Contemporary Marine Sediments", Geochim. Cosmochin. Acta 43, 1715-1725 (1979).

Quemard, A., J. C. Sacchettini, A. Dessen, C. Vilcheze, R. Bittman, W. R. Jacobs, Jr., and J. S. Blanchard, "Enzymatic Characterization of the Target for Isoniazid in Mycobacterium tuberculosis", Biochemistry 34, 8235-8241 (1995).

Radwan, S., N. Sorkhoh, and I. El-Nemr, "Oil Biodegradation Around Roots", Nature 376, 302302 (1995).

Ramadan M. A., O.M. El-Tayeb, and M. Alexander, "Inoculum Size as a Factor Limiting Success of Inoculation for Biodegradation", Applied Environmental Microbiology 56, 1392-1396.(1990).

Ramanand, K., M. Sharmila, N. Singh, and N. Sethunathan, "Metabolism of Carbamate Insecticides by Resting Cells and Cell-Free Preparations of a Soil Bacterium, Arthrobacter sp", Bulletin of Environmental Contaminant Toxicology 46, 380-386 (1991).

Rashidi, M. and F. Milanovich, "3D Imaging of Flow and Transport in Porous Media" AIChE Annual Meeting, Denver, August 14-19 (1994).

Rashidi, M., "Simulation of Contaminant Flow in a Laboratory-Scale Porous System", EUROPTO, Paper No. 2504-85, June 10-23 (1995).

Rashidi, M. and R. Rinker, "Microscale Transport in Porous Media" 5th Congress of Chemical Engineering, San Diego, CA, July 14-18 (1996). 
Rashidi, M. and E. Dickenson, "Small Scale Flow Processes in Aqueous Heterogeneous Porous Media" ASME Fluids Engineering Conference, San Diego, CA, July 7-11 (1996).

Rashidi, M., L. Peurrung, A. Tompson, and T. Kulp, "Experimental Analysis of Pore-Scale Flow and Transport in Porous Media", Advances in Water Resources 19(3), 163-180 (1996a).

Rashidi, M., A. Tompson, T. Kulp, and L. Peurrung, "3D Microscopic Measurement and Analysis of Chemical Flow and Transport in Porous Media", J. Fluids Eng. 118, 1-11 (1996b).

Rashidi, M., Non-Invasive Monitoring of Multiphase Flows, Editors: J. Chaouki, F. Larachi, and M.P. Dudukovic, Elsevier Publishing Co., in press (1996).

Raymond, R.L., "Reclamation of Hydrocarbon Contaminated Groundwaters", Patent Office, Washington, D.C. Patent No. 3, 846, 290, Patented November 5 (1974).

Reynolds, P. J., P. Sharma, G. E. Jenneman, and M. J. McInerney, "Mechanisms of Microbial Movement in subsurface Materials", Applied and Environmental Microbiology 55, 2280-2286 (1989).

Ridgway, H.F., J. Safarik, D. Phipps, and D. Carl, "Identification and Catabolic Activity of WellDerived Gasoline-Degrading Bacteria from a Contaminated Aquifer", Applied Environmenal Microbiology 56, 3565-3575 (1990).

Rifai, H.S., P.B. Bedient, R.C. Borden, and J.F. Haasbeek, "BIOPLUME II - Computer Model of Two-Dimensional Transport under the Influence of Oxygen Limited Biodegradation in Groundwater, User's Manual, Version 1.0, Rice University, Houston, TX (1987).

Rifai, H.S. and P.B. Bedient, "Comparison of Biodegradation Kinetics With an Instantaneous Reaction Model for Groudwater", Water Resources Research 26, (4), 637-645 (1990).

Ritter, W. F., "A Review of Bioremediation of Contaminated Soils and Groundwater", Journal of Environmental Science A30(2); 333-357 (1995).

Rittmann, B.E. and J.A. MacDonald, "Performance Standard for In Situ Bioremediation", Environmental Science and Technology 27(10), 1974-1979 (1993).

Rouse, J.D., D.A. Sabatini, and J.H. Harwell, "Minimizing Losses Using Twin-head Anionic Surfactant in Subsurface Remediation", Environmental Science and Technology 27(10) 20722078 (1993).

Russo, D., "On the Velocity Covariance and Transport Modeling in Heterogeneous Anisotropic Porous Formations; 1. Saturated Flow", Water Resources Research 31(1) 129-137 (1995a).

Russo, D., "On the Velocity Covariance and Transport Modeling in Heterogeneous Anisotropic Porous Formations; 2. Unsaturated Flow", Water Resources Research 31(1), 139-145 (1995b).

Sabatini, D.A., R.C. Knox, and J.H. Harwell., "Surfactant-enhanced Subsurface Remediation: Emerging Technologies", ACS Symposium Series 594, Washington. D.C.: American Chemical Society, (1995).

Sander, P., R.M. Wittich, P. Fortnagel, H. Wilkes, and W. Francke, "Degradation of 1,2,4Trichloro- and 1,2,4,5-Tetrachlorobenzene by Pseudomonas Strain", Applied Environmental Microbiology 57, 1430-1440 (1991).

Sanseverino, J., "Surfactant-Enhanced Bioremediation of Polynuclear Aromatic Hydrocarbons in Coke Waste", Remediation of Hazardous Waste Contaminated Soils, editors: D.L. Wise and D.J. Trantolo, Marcel Dekker, Inc., 345-372 (1994). 
Servais P., G. Billen, C. Ventres, and G. P. Bablon, "Microbial Activity in Granular Activated Carbon Filters at the Choisy-le-Roi Treatment Plant", Journal of American Water Works Association 83, 62-68 (1991).

Shah, N. N., M. L. Hanna, K. J. Jackson, and R. T. Taylor, "Batch Cultivation of Methylosinus Trichosporium OB3b: IV. Production of Hydrogen-Driven Soluble or Particulate Methane Monooxygenase Activity", Biotechnology and Bioengineering 45, 229-238, (1995).

Shiau, B.J., D.A. Sabatini, and J.H. Harwell, "Solubilization and Microemulsification of DNAPLs using Edible Surfactants", Ground Water 32(4), 561-569 (1994).

Shonnard, D.R. and R.L. Bell,"The Effects of Nonlinear Sorption on the Diffusion of Volatile Organic Compounds from Air-Dry Soils-A Theoretical Study", Journal of Hazardous Materials 37 (3) $397-414$ (1994).

Sims R.C. and M.R. Overcash, "Fate of Polynuclear Aromatic Compounds (PNAS) in Soil-Plant Systems, Residue Review 88, 1-68 (1983).

Sims, J.L., R.C. Sims, and J.E. Matthews, "Approach to Bioremediation of Contaminated Soil", Hazardous Waste and Hazardous Materials 7(2) 117-149 (1990).

Sims, J.L., R.C. Sims, R.R. Dupont, J.E. Mathews, and H.H. Russel, "In Situ Bioremediation of Contaminated Unsaturated Soils", EPA Report, Office of Research and Development, Washington, D.C., EPA/540/S-93/501 (1993).

Speitel G.E., M. Turakhia, and C.J. Lu,"Initiation of Micropollutant Biodegradation in Virgin Granular Activated Carbon Columns", Journal of American Water Works Association 81, 168176 (1989).

Speitel, G. E., R. C. Thompson, and D. Weissman, "Biodegradation Kinetics of Methylosinus Trichosporium OB3b at Low Concentrations of Chloroform in the Presence and Absence of Enzyme Competition by Methane", Water Research 27, 15-24 (1993).

Stormo, K. E., and R. L. Crawford, "Preparation of Encapsulated Microbial Cells for Environmental Applications", Applied and Environmental Microbiology 58, 727-730 (1992).

Tang, Y. and M.M. Aral, "Contaminant Transport in Layered Porous Media 1. General Solution", Water Resources Research 28, 1389-1397 (1992a).

Tang, Y. and M.M. Aral, "Contaminant Transport in Layered Porous Media 2. Applications", Water Resources Research 28, 1399-1406 (1992b).

Taylor, R.T., M.L. Hanna, N.N. Shah, and D.R. Shonnard, "In Situ Bioremediation of Trichloroethylene-Contaminated Water by a resting-Cell Methanotrophic Microbial Filter", Journal of Hydrological Science 38(4), 323-342 (1993).

Taylor, R.T. and L.M. Hanna, "Laboratory Treatability Studies for a Resting-Cell In situ Microbial Filter Bioremediation Strategy", Proceedings of the In Situ and On-Site Bioreclamation, Third International Symposium, April 24-27, San Diego, CA, Battelle Press (1995).

Thomas, J. M., and C. H. Ward, "In-Situ Biorestoration of Organic Contaminants in the Subsurface", Environmental Science and Technology 23, 760-766 (1989).

Tomasi, I., I. Artaud, Y. Bertheau, and D. Mansuy, "Metabolism of Polychlorinated Phenols by Pseudomonas cepacia AC1100: Determination of the First Two Steps and Specific Inhibitory Effect of Methimazole", Journal of Bacteriology 177, 307-311 (1995).

U.S. Environmental Protection Agency. "Hazardous Waste Land Treatment", Report, EPA/SW874 (1983). 
U.S. Environmental Protection Agency. "Review of In-Place Treatment Techniques for Contaminated Surface Soils", Report, EPA-540/2-84-0003a (1984).

U.S. Environmental Protection Agency. "Permit Guidance Manual on Hazardous Waste Land Treatment Demonstrations", Report, EPA-530/SW-86-032 (1986).

U.S. Environmental Protection Agency, "Handbook on In Situ Treatment of Hazardous WasteContaminated Soils", Report, EPA/540/2-90-002 (1990).

Venisse, A., M. Riviere, J. Vercauteren, and G. Puzo, "Structure Analysis of the Mannan Region of Lipoarabinomannan from Mycobacterium Bovis BCG", Journal of Biological Chemistry 270, 15012-15021 (1995).

Wan, J., T. K. Tokunaga, and C. F. Tsang, "Bacterial Sedimentation Through a Porous Medium" Water Resources Research 31(7) 1627-1636 (1995).

Wilson, J.T. and B.H. Wilson, "Biotransformation of Trichloroethylene in Soil", Applied and Environmental Microbiology 49, 242-243 (1985).

Wilson, K.W., "Zero-Valent Metals Provide Possible Solution to Groundwater Problems" Chemical and Engineering News 73(27), 19-22 (1995).

Yao, K.M., M.T. Habibian, and C.R. O'Melia, "Water and Wastewater Filtration: Concepts and Applications", Environmental Science \& Technology 5, 1105-1112 (1971).

Yeh, T.C., L.W. Gelhar, and A.L. Gutjahr, "Stochastic Analysis of Unsaturated Flow in Heterogeneous Soils, 1, Statistically Isotropic Media", Water Resources Research 21, 447-456 (1985a).

Yeh, T.C., L.W. Gelhar, and A.L. Gutjahr, "Stochastic Analysis of Unsaturated Flow in Heterogeneous Soils, 2, Statistically Anisotropic Media with Variable $\alpha$ ", Water Resources Research 21, 457-464 (1985b).

Ying, A., J.Duffy, G. Shepherd, and D. Wright, "Bioremediation of Heavy Petroleum Oil in Soil at a Railroad Maintenance Yard", Petroleum Contaminated Soils, edited by C.E. Bell, 227-238, Lewis Publishers, Inc. , Chelsea, Michigan (1989).

Zacharias, B., E. Lang, and H.H. Hanert, "Biodegradation of Chlorinated Aromatic Hydrocarbons in Slow Sand Filters Simulating Conditions in Contaminated Soil-Pilot Study For In-Situ Cleaning of an Industrial Site", Water Research 29, 1663-1671 (1995).

Zaidi, B. R., Y. Murakami, and M. Alexander, "Predation and Inhibitors in Lake water Affect the Success of Inoculation To enhance Biodegradation of Organic Chemicals", Environmental Science and Technology 23, 859-863 (1989). 
Table I. Characteristics of Bacteria

\begin{tabular}{|c|c|c|c|c|c|c|c|}
\hline BACTERIA & TYPES & SLaES (um) & ENVIRONMENT & FLUORESCENCE & $\begin{array}{l}\text { DEGRADES } \\
\text { CONTAMINANTS }\end{array}$ & CASE STUDIES & BEFERENCES \\
\hline $\begin{array}{l}\text { Acinetobacter } \\
\text { calcoaceticus }\end{array}$ & $\begin{array}{l}\text { Gram-negative } \\
\text { Neisseriaceae } \\
\text { Spheres }\end{array}$ & $\begin{array}{l}\text { Diameter }= \\
1.0-1.2\end{array}$ & $\begin{array}{l}\text { Found in soil, water and } \\
\text { associated with man and } \\
\text { animals. Aerobic. } \\
30-32^{\circ} \mathrm{C}, \mathrm{pH}=7.0\end{array}$ & $\begin{array}{l}\text { No fluorescent } \\
\text { pigment }\end{array}$ & $\begin{array}{l}\text { polychlorinated biphenyl's, } \\
\text { trichloroethylene, ammonium } \\
\text { salts, acetate, butyrate, pyruvate }\end{array}$ & $\begin{array}{l}\text { Rice University, } \\
\text { Houston, Texas }\end{array}$ & $\begin{array}{l}\text { Thomas et al. (1989) } \\
\text { Bergey's Manual of } \\
\text { Determinative } \\
\text { Bacteriology. 8th } \\
\text { Edition. (1974) }\end{array}$ \\
\hline $\begin{array}{l}\text { Aquaspirillum } \\
\text { anlus }\end{array}$ & $\begin{array}{l}\text { Gram-negative } \\
\text { Spirillaceae rods }\end{array}$ & $\begin{array}{l}\text { Width }=1.4-1.5 \\
\text { Length }=7-15\end{array}$ & Strict aerobe & Fluorescent pigment & $\begin{array}{l}\text { organic acids, alcohols, amino } \\
\text { acids }\end{array}$ & N/A & $\begin{array}{l}\text { CRC Hand Book of } \\
\text { Microbiology } \\
\text { 2nd Edition (1977) }\end{array}$ \\
\hline $\begin{array}{l}\text { Aquaspirillum } \\
\text { bengal }\end{array}$ & $\begin{array}{l}\text { Gram-negative } \\
\text { Spirillaceae rods }\end{array}$ & $\begin{array}{l}\text { Width }=0.9-1.2 \\
\text { Length }=5.2-22\end{array}$ & Aerobic to microaerophilic & Fluorescent pigment & $\begin{array}{l}\text { organic acids, alcohols, amino } \\
\text { acids }\end{array}$ & $\overline{\mathrm{N} / \mathrm{A}}$ & $\begin{array}{l}\text { CRC Hand Book } \\
\text { (1977) }\end{array}$ \\
\hline $\begin{array}{l}\text { Aquaspirillum } \\
\text { itersonii }\end{array}$ & $\begin{array}{l}\text { Gram-negative } \\
\text { Soirillaceae rods }\end{array}$ & $\begin{array}{l}\text { Width }=0.4-0.6 \\
\text { Length }=2.0-7.0\end{array}$ & Strict aerobe & Fluorescent pigment & $\begin{array}{l}\text { organic acids, alcohols, amino } \\
\text { acids }\end{array}$ & N/A & $\begin{array}{l}\text { CRC Hand Book } \\
\text { (1977) }\end{array}$ \\
\hline $\begin{array}{l}\text { Aquaspirillum } \\
\text { serpens }\end{array}$ & $\begin{array}{l}\text { Gram-negative } \\
\text { Spirillaceae rods }\end{array}$ & $\begin{array}{l}\text { Width }=0.5-1.0 \\
\text { Length }=5-35\end{array}$ & Strict aerobe & Fluorescent pigment & $\begin{array}{l}\text { organic acids, alcohols, amino } \\
\text { acids }\end{array}$ & $\mathrm{N} / \mathrm{A}$ & $\begin{array}{l}\text { CRC Hand Book } \\
\text { (1977) }\end{array}$ \\
\hline $\begin{array}{l}\text { Arthobacter } \\
\text { sepedonicum }\end{array}$ & $\begin{array}{l}\text { Gram-positive } \\
\text { Asperogenous } \\
\text { rods }\end{array}$ & $\begin{array}{l}\text { Width }=0.4-0.8 \\
\text { Length }=1-6\end{array}$ & $\begin{array}{l}\text { Abundantly distributed in } \\
\text { soil, Strict aerobes }\end{array}$ & $\begin{array}{l}\text { No Fluorescent } \\
\text { pigment }\end{array}$ & $\begin{array}{l}\text { pentachlorophenol, carbfurem, } \\
\text { isopropyl } N \text {-phenylcarbamate, } \\
\text { carbaryl beniocarb, carbosulfan }\end{array}$ & $\begin{array}{l}\text { Cornell University } \\
\text { Ithaca, N.Y. } \\
\text { Central Rice Res. } \\
\text { Inst. } \\
\text { Cuttack. India } \\
\end{array}$ & $\begin{array}{l}\text { Edgehill et al. (1983) } \\
\text { Ramanand et al. } \\
\text { (1991) }\end{array}$ \\
\hline $\begin{array}{l}\text { Azomonas } \\
\text { agilis }\end{array}$ & $\begin{array}{l}\text { Gram-negative } \\
\text { Azomonas rods }\end{array}$ & Diameter $=2.0$ & $\begin{array}{l}\text { Found in soils and water } \\
\text { bodies. Aerobic } \\
\text { pH 7.0-78.5, 20-30 }{ }^{\circ} \mathrm{C}\end{array}$ & $\begin{array}{l}\text { White fluorescent } \\
\text { pigment }\end{array}$ & carbohydrates & N/A & $\begin{array}{l}\text { CRC Hand Book } \\
\text { (1977) } \\
\text { Bergey's Manual } \\
\text { (1974) }\end{array}$ \\
\hline $\begin{array}{l}\text { Azomonas } \\
\text { insignis }\end{array}$ & $\begin{array}{l}\text { Gram-negative } \\
\text { Azomonas rods }\end{array}$ & Diameter $=2.0$ & $\begin{array}{l}\text { Found in soils and water } \\
\text { bodies. Aerobic } \\
\text { pH } 7.0-7.5,20-30^{\circ} \mathrm{C}\end{array}$ & $\begin{array}{l}\text { No fluorescent } \\
\text { pigment }\end{array}$ & carbohydrates & $\overline{N / A}$ & $\begin{array}{l}\text { CRC Hand Book } \\
\text { (1977) } \\
\text { Bergey's Manual } \\
(1974)\end{array}$ \\
\hline $\begin{array}{l}\text { Azomonas } \\
\text { marcocytoeres }\end{array}$ & $\begin{array}{l}\text { Gram-negative } \\
\text { Azomonas rods }\end{array}$ & Diameter $=2.0$ & $\begin{array}{l}\text { Found in soils and water } \\
\text { bodies. Aerobic } \\
\text { pH } 7.0-7.5,20-30^{\circ} \mathrm{C}\end{array}$ & $\begin{array}{l}\text { White fluorescent } \\
\text { pigment }\end{array}$ & carbohydrates, mannitol & N/A & $\begin{array}{l}\text { CRC Hand Book } \\
\text { (1977) } \\
\text { Bergey's Manual } \\
\text { (1974) }\end{array}$ \\
\hline $\begin{array}{l}\text { Azotobacter } \\
\text { beijerinckii }\end{array}$ & $\begin{array}{l}\text { Gram-negative } \\
\text { Azotobacter rods }\end{array}$ & Diameter $=2.0$ & $\begin{array}{l}\text { found in soils and water } \\
\text { bodies. Aerobic } \\
\text { pH 7.0-7.5. 20-30 }{ }^{\circ} \mathrm{C}\end{array}$ & $\begin{array}{l}\text { No fluorescent } \\
\text { pigment }\end{array}$ & carbohydrates & N/A & $\begin{array}{l}\text { CRC Hand Book } \\
\text { (1977) } \\
\text { Bergey's Manual } \\
\text { (1974) }\end{array}$ \\
\hline $\begin{array}{l}\text { Azotobacter } \\
\text { chroococcum }\end{array}$ & $\begin{array}{l}\text { Gram-negative } \\
\text { Azotobacter rods }\end{array}$ & Diameter $=2.0$ & $\begin{array}{l}\text { Found in soils and water } \\
\text { bodies. Aerobic } \\
\text { pH 7.0-7.5, 20-30 } 30^{\circ} \mathrm{C}\end{array}$ & $\begin{array}{l}\text { No fluorescent } \\
\text { pigment }\end{array}$ & carbohydrates, mannitol & $\overline{\mathrm{N} / \mathrm{A}}$ & $\begin{array}{l}\text { CRC Hand Book } \\
\text { (1977) } \\
\text { Bergey's Manual } \\
(1974)\end{array}$ \\
\hline $\begin{array}{l}\text { Azotobacter } \\
\text { paspali }\end{array}$ & $\begin{array}{l}\text { Gram-negative } \\
\text { Azotobacter rods }\end{array}$ & Diameter $=2.0$ & $\begin{array}{l}\text { Found in soils and water } \\
\text { bodies. Aerobic } \\
\text { pH 7.0-7.5, 20-30 } 30^{\circ} \mathrm{C}\end{array}$ & $\begin{array}{l}\text { Green fluorescent } \\
\text { pigment }\end{array}$ & carbohydrates & N/A & $\begin{array}{l}\text { CRC Hand Book } \\
\text { (1977) } \\
\text { Bergey's Manual } \\
\text { (1974) }\end{array}$ \\
\hline $\begin{array}{l}\text { Azotobacter } \\
\text { vinelandii }\end{array}$ & $\begin{array}{l}\text { Gram-negative } \\
\text { Azotobacter rods }\end{array}$ & Diameter $=2.0$ & $\begin{array}{l}\text { Found in soils and water } \\
\text { bodies. Aerobic } \\
\mathrm{pH} 7.0-7.5,20-30^{\circ} \mathrm{C}\end{array}$ & $\begin{array}{l}\text { Green fluoresecnt } \\
\text { pigment }\end{array}$ & Mannitol, rhamnose & N/A & $\begin{array}{l}\text { Bergey's Manual } \\
\text { (1974) }\end{array}$ \\
\hline $\begin{array}{l}\text { Bacillus } \\
\text { anthracis }\end{array}$ & $\begin{array}{l}\text { Gram-positive } \\
\text { Bacillaceae rods }\end{array}$ & $\begin{array}{l}\text { Width }=1.0-1.2 \\
\text { Length }=3.0-5.0\end{array}$ & $\begin{array}{l}\text { Found in cattle. Aerobic. } \\
\mathrm{pH} 7.0-7.4,15-40^{\circ} \mathrm{C} \\
\left(\text { opt } 37^{\circ} \mathrm{C}\right)\end{array}$ & $\begin{array}{l}\text { Fluorescent-antibody } \\
\text { stain }\end{array}$ & chitin, amygdaline & $\begin{array}{l}\text { Gulf Oil Corp, U. } \\
\text { of Houston : } \\
\text { Houston, TX } \\
\end{array}$ & Kalish et aí. (1964) \\
\hline $\begin{array}{l}\text { Bacillus } \\
\text { cereus }\end{array}$ & $\begin{array}{l}\text { Gram-positive } \\
\text { Bacillaceae rods }\end{array}$ & $\begin{array}{l}\text { Width }=1.0-1.4 \\
\text { Length }=3.5-12\end{array}$ & $\begin{array}{l}\text { Food poison Facultatively } \\
\text { aerobic. } 37^{\circ} \mathrm{C}\end{array}$ & $\begin{array}{l}\text { Fluorescent-antibody } \\
\text { stain }\end{array}$ & chitin, amygdaline & $\begin{array}{l}\text { Guif Oil Corp. } \\
\text { Houston, TX }\end{array}$ & Kalish et al. (1964) \\
\hline $\begin{array}{l}\text { Bacillus } \\
\text { megaterium }\end{array}$ & $\begin{array}{l}\text { Gram-positive } \\
\text { Bacillaceae rods }\end{array}$ & $\begin{array}{l}\text { Width }=1.6-2.0 \\
\text { Length }=3.7-9.7\end{array}$ & $\begin{array}{l}\text { Found in soils Strictly } \\
\text { aerobic }\end{array}$ & $\begin{array}{l}\text { Fluorescent-antibody } \\
\text { stain }\end{array}$ & chitin, amygdaline & $\begin{array}{l}\text { Gulf Oil Corp. } \\
\text { Houston. TX }\end{array}$ & Kalish et ail. (1964) \\
\hline $\begin{array}{l}\text { Bacillus } \\
\text { subtils }\end{array}$ & $\begin{array}{l}\text { Gram-positive } \\
\text { Bacillaceae rods }\end{array}$ & $\begin{array}{l}\text { Width }=0.9-1.05 \\
\text { Length }=1.8-4.8\end{array}$ & $\begin{array}{l}\text { Found in air, dust, and } \\
\text { brack water. Aerobic. } \\
50^{\circ} \mathrm{C} \text {, pH } 5.5-8.5\end{array}$ & $\begin{array}{l}\text { Fluorescent-antibody } \\
\text { stain }\end{array}$ & chitin, amygdaline & $\begin{array}{l}\text { U. Southern Cal. } \\
\text { Los Angeles, CA }\end{array}$ & Jang et al. (1983) \\
\hline $\begin{array}{l}\text { Cellumonas } \\
\text { flavigena }\end{array}$ & $\begin{array}{l}\text { Gram-positive } \\
\text { Asorogenous rods }\end{array}$ & $\begin{array}{l}\text { Width }=0.5 \\
\text { Length }=0.7-2.0\end{array}$ & $\begin{array}{l}\text { Found in soil. Aerobic to } \\
\text { anaerobic. } \mathrm{pH} 7.0,30^{\circ} \mathrm{C}\end{array}$ & $\begin{array}{l}\text { No Fluorescent } \\
\text { pigment }\end{array}$ & $\begin{array}{l}\text { n-alkane C-20 to C-25, celluiose } \\
\text { carbohydrates, organic and } \\
\text { amino acids }\end{array}$ & $\overline{\mathrm{N} / \mathrm{A}}$ & $\begin{array}{l}\text { CRC Hand Book } \\
\text { (1977) }\end{array}$ \\
\hline $\begin{array}{l}\text { Clostridium } \\
\text { thermoaceticum }\end{array}$ & \begin{tabular}{l|} 
Gram-positive \\
Streptoeoccus rods \\
\end{tabular} & \begin{tabular}{|l|} 
Width $=0.3-1.5$ \\
Length $=1.3-14$ \\
\end{tabular} & $\begin{array}{l}\text { Found in soil, in marine } \\
\text { and fresh water sediments }\end{array}$ & $\begin{array}{l}\text { No fluorescent } \\
\text { pigment }\end{array}$ & carbon terachloride & N/A & $\begin{array}{l}\text { CRC Hand Book } \\
\text { (1977) }\end{array}$ \\
\hline $\begin{array}{l}\text { Conynebacterium } \\
\text { sepedonicum }\end{array}$ & $\begin{array}{l}\text { Gram-positive } \\
\text { Asoorogenous } \\
\text { rods }\end{array}$ & $\begin{array}{l}\text { Width }=0.4-0.6 \\
\text { Length }=0.8-1.2\end{array}$ & $\begin{array}{l}\text { Found in soils. Aerobic to } \\
\text { anaerobic. } 20-23^{\circ} \mathrm{C}\end{array}$ & $\begin{array}{l}\text { No fluorescent } \\
\text { pigment }\end{array}$ & $\begin{array}{l}\text { p-nitrophenol, polychloinated } \\
\text { biphenyl's }\end{array}$ & $\begin{array}{l}\text { Comell U. Ithaca } \\
\text { N. Y. }\end{array}$ & Zaidi et al. (1989) \\
\hline $\begin{array}{l}\text { Escherichia } \\
\text { coli }\end{array}$ & \begin{tabular}{l|} 
Gram-negative \\
Enterobacteriaceae \\
rods
\end{tabular} & $\begin{array}{l}\text { Width }=0.4-0.7 \\
\text { Length }=1.0-3.0\end{array}$ & $\begin{array}{l}\text { Found in lower part of the } \\
\text { intestine of warm blooded } \\
\text { animals. Anaerobic }\end{array}$ & $\begin{array}{l}\text { No Fluorescent } \\
\text { pigment }\end{array}$ & $\begin{array}{l}\text { carbon tetrachioride, diesel fuel, } \\
\text { and crude oil }\end{array}$ & $\begin{array}{l}\text { U. of Oklahoma, } \\
\text { Norman, OK }\end{array}$ & $\begin{array}{l}\text { Reynoids et al. } \\
\text { (1989) }\end{array}$ \\
\hline $\begin{array}{l}\text { Flavobacterium } \\
\text { sepedonicum }\end{array}$ & $\begin{array}{l}\text { Gram-negative } \\
\text { Flavobacterium } \\
\text { rods }\end{array}$ & $\begin{array}{l}\text { Width }=0.4-1.0 \\
\text { Length }=0.7-6.0\end{array}$ & $\begin{array}{l}\text { Found in soil and in water } \\
\text { bodies, including sewage } \\
\text { and sea. Facultatively } \\
\text { anaerobic }\end{array}$ & $\begin{array}{l}\text { No Fluorescent } \\
\text { pigmnet }\end{array}$ & $\begin{array}{l}\text { 4-(2,4-dichlorophenoxy)-butyric } \\
\text { acid, pentachlorophenol, } \\
\text { chlorophenol }\end{array}$ & $\begin{array}{l}\text { U. of Idaho, } \\
\text { Moscow, Idaho }\end{array}$ & Stormo et al. (1992) \\
\hline $\begin{array}{l}\text { Klesbsiella } \\
\text { pueumoniae }\end{array}$ & \begin{tabular}{l|} 
Gram-negative \\
Enterobacteriaceae \\
rods
\end{tabular} & $\begin{array}{l}\text { Width }=0.3-1.5 \\
\text { Length }=0.7-6.0\end{array}$ & $\begin{array}{l}\text { Found in soil and ground } \\
\text { water. Facultatively } \\
\text { anaerobic. } 35-37^{\circ} \mathrm{C} \text {, } \\
\text { pH } 7.2\end{array}$ & $\begin{array}{l}\text { No Fluorescent } \\
\text { pigment }\end{array}$ & $\begin{array}{l}\text { diesel fuel, crude oil, phenol, } \\
\text { 2,3-butanediol, }\end{array}$ & $\begin{array}{l}\text { U. of Calgary, } \\
\text { Alberta, Canada }\end{array}$ & Macleod et al. (1988) \\
\hline $\begin{array}{l}\text { Methanobacterium } \\
\text { thermoautotrophicum }\end{array}$ & $\begin{array}{l}\text { Gram-positive } \\
\text { Methanobacteria- } \\
\text { ceae rods }\end{array}$ & $\begin{array}{l}\text { Width }=0.35-0.6 \\
\text { Length }=3.0-7.0\end{array}$ & $\begin{array}{l}\text { Found in sewage sludge. } \\
\text { Strictly anaerobic. } \\
\text { pH } 7.2-7.6,65-70^{\circ} \mathrm{C}\end{array}$ & $\begin{array}{l}\text { No Fluorescent } \\
\text { pigment }\end{array}$ & $\begin{array}{l}\text { 1,1,1-trichloroethane, carbon } \\
\text { dioxide }\end{array}$ & N/A & $\begin{array}{l}\text { Zinsser } \\
\text { Microbiology, } \\
20 \text { th Edition (1992) }\end{array}$ \\
\hline $\begin{array}{l}\text { Methanosarcina } \\
\text { barkeri }\end{array}$ & $\begin{array}{l}\text { Gram-positive } \\
\text { Methanobacteria- } \\
\text { ceae cocci }\end{array}$ & Diameter $=1.5-2$ & $\begin{array}{l}\text { Found in sewage sludge } \\
\text { and mud. } \mathrm{pH} 7.0\end{array}$ & $\begin{array}{l}\text { No Fluorescent } \\
\text { pigment }\end{array}$ & $\begin{array}{l}\text { carbon terrachloride, carbon } \\
\text { dioxide }\end{array}$ & $\overline{N / A}$ & $\begin{array}{l}\text { CRC Hand Book } \\
\text { (1977) }\end{array}$ \\
\hline
\end{tabular}




\begin{tabular}{|c|c|c|c|c|c|c|c|}
\hline $\begin{array}{l}\text { Methylosinus } \\
\text { trichosporium }\end{array}$ & $\begin{array}{l}\text { Gram-positive } \\
\text { Methanobacteria- } \\
\text { ceae cocci }\end{array}$ & $\begin{array}{l}\text { Diameter }=0.25 \text {. } \\
0.5\end{array}$ & $\begin{array}{l}\text { Found in soil sewage } \\
\text { sludge, and mud. pH } 6.0 \\
-8.0 \text { (opt } 6.8-7.5)\end{array}$ & $\begin{array}{l}\text { No Fluorescent } \\
\text { pigment }\end{array}$ & $\begin{array}{l}\text { carbontetrachloride,Tetrachloroe } \\
\text { thane,Trichloroethene }\end{array}$ & $\begin{array}{l}\text { LLNL, Livermore, } \\
\text { CA } \\
\text { ORNL, OakRidge, } \\
\text { TN }\end{array}$ & $\begin{array}{l}\text { Duba et al. (1996) } \\
\text { Palumbo et al. (1995) }\end{array}$ \\
\hline $\begin{array}{l}\text { Micrococcus } \\
\text { roseus }\end{array}$ & $\begin{array}{l}\text { Gram-positive } \\
\text { Micrococcaceae } \\
\text { cocci }\end{array}$ & $\begin{array}{l}\text { Diameter }=0.5- \\
3.5\end{array}$ & $\begin{array}{l}\text { Found in fresh water and in } \\
\text { soils. pH 5.2-6.5 (opt } 6.2 \text { ) } \\
25^{\circ} \mathrm{C} \text {. Aerobic. }\end{array}$ & $\begin{array}{l}\text { No Fluorescent } \\
\text { pigment }\end{array}$ & $\begin{array}{l}\text { naphthalene, phenanthrene, } \\
\text { fluoranthrene, pyrene, } \\
\text { nitropyrene, methyl- } \\
\text { chloanthrene, 6-nitrochrysene }\end{array}$ & N/A & $\begin{array}{l}\text { Bergey's Manual } \\
\text { (1974) }\end{array}$ \\
\hline $\begin{array}{l}\text { Mycobacterium } \\
\text { bovis }\end{array}$ & $\begin{array}{l}\text { Acid-fast Myco- } \\
\text { bccteriaceae rods }\end{array}$ & $\begin{array}{l}\text { Width }=0.2-0.6 \\
\text { Length }=1-10\end{array}$ & Aerobic, $37^{\circ} \mathrm{C}$ & $\begin{array}{l}\text { No Fluorescent } \\
\text { pigment }\end{array}$ & chlorophenol & $\begin{array}{l}\text { CNRS, Bordeaux } \\
\text { Cedex, France }\end{array}$ & Venisse et al. (1995) \\
\hline $\begin{array}{l}\text { Mycobacterium } \\
\text { leprae }\end{array}$ & $\begin{array}{l}\text { Acid-fast Myco- } \\
\text { bacteriaceae rods }\end{array}$ & $\begin{array}{l}\text { Width }=0.3-0.5 \\
\text { Length }=1.0-8.0\end{array}$ & Aerobic, $37^{\circ} \mathrm{C}$ & $\begin{array}{l}\text { No Fluorescent } \\
\text { pigment }\end{array}$ & chlorophenol & $\begin{array}{l}\text { Aga Khan U. } \\
\text { Karachi, Pakistan }\end{array}$ & Hussain et al. (1995) \\
\hline $\begin{array}{l}\text { Mycobacterium } \\
\text { paraffinicum }\end{array}$ & $\begin{array}{l}\text { Acid-fast Myco- } \\
\text { bacteriaceae rods }\end{array}$ & $\begin{array}{l}\text { Width }=0.5-0.7 \\
\text { Length }=3.0-7.0\end{array}$ & $\begin{array}{l}\text { Found in liquid minerial } \\
\text { salt medium. } 37^{\circ} \mathrm{C}\end{array}$ & $\begin{array}{l}\text { No Fluorescent } \\
\text { pigment }\end{array}$ & paraffins, $C_{2}-C_{10}$ & N/A & $\begin{array}{l}\text { Bergey's Manual. } \\
\text { (1974) }\end{array}$ \\
\hline $\begin{array}{l}\text { Mycobacterium } \\
\text { sepedonicum }\end{array}$ & $\begin{array}{l}\text { Acid-fast Myco- } \\
\text { bacteriaceae rods }\end{array}$ & $\begin{array}{l}\text { Width }=0.2-0.6 \\
\text { Length }=1.010 .0\end{array}$ & Aerobic, $37^{\circ} \mathrm{C}$ & $\begin{array}{l}\text { No Fluorescent } \\
\text { pigment }\end{array}$ & $\begin{array}{l}\text { pyrene, 2-methyl } \\
\text { naphthalenephenanthrene, } \\
\text { fluoranthene, chlorophenol }\end{array}$ & $\mathrm{N} / \mathrm{A}$ & $\begin{array}{l}\text { CRC Hand Book } \\
(1977)\end{array}$ \\
\hline $\begin{array}{l}\text { Mycobacterium } \\
\text { tuberculosis }\end{array}$ & $\begin{array}{l}\text { Acid-fast Myco- } \\
\text { bacteriaceae rods }\end{array}$ & $\begin{array}{l}\text { Width }=0.3-0.6 \\
\text { Length }=1.0-4.0\end{array}$ & $\begin{array}{l}\text { Aerobic, } 37^{\circ} \mathrm{C} \\
\mathrm{pH}=6.0-7.6(\text { opt } 7.0)\end{array}$ & $\begin{array}{l}\text { No Fluorescent } \\
\text { pigment }\end{array}$ & glucose, glycerol, chlorophenol & $\begin{array}{l}\text { Howard Hughes } \\
\text { Med. Inst. NY }\end{array}$ & Quemad et al. (1995) \\
\hline $\begin{array}{l}\text { Mycobacterium } \\
\text { ulcerans }\end{array}$ & $\begin{array}{l}\text { Acid-fast Myco- } \\
\text { bacteriaceae rods }\end{array}$ & $\begin{array}{l}\text { Width }=0.5 \\
\text { length }=1.0-8.0\end{array}$ & $\begin{array}{l}\text { Aerobic } \\
\text { Temp }=30-33^{\circ} \mathrm{C}\end{array}$ & $\begin{array}{l}\text { No Fluorescent } \\
\text { pigment }\end{array}$ & chlorophenol & N/A & $\begin{array}{l}\text { Zinsser } \\
\text { Microbiology. (1977) }\end{array}$ \\
\hline $\begin{array}{l}\text { Nitrosomonas } \\
\text { europea }\end{array}$ & $\begin{array}{l}\text { Gram-negative } \\
\text { Nitrobacteriaceae } \\
\text { rods }\end{array}$ & $\begin{array}{l}\text { Width }=0.8-0.9 \\
\text { Length }=1.0-2.0\end{array}$ & $\begin{array}{l}\text { Areobic, } 25-30^{\circ} \mathrm{C} \text {, } \\
\text { pH 7.5-8.0 }\end{array}$ & $\begin{array}{l}\text { No Fluorescent } \\
\text { pigment }\end{array}$ & $\begin{array}{l}\text { 1,2,3-trichloropropane, } \\
\text { trichloroethene, 1,1,2- } \\
\text { trichloroethane,chloroethane, } \\
\text { trichloromethane,dichloro- } \\
\text { methane, 1, 1-dichloroethane }\end{array}$ & N/A & $\begin{array}{l}\text { Bergey's Manual } \\
(1974)\end{array}$ \\
\hline $\begin{array}{l}\text { Oceanospirillum } \\
\text { beijinckii }\end{array}$ & $\begin{array}{l}\text { Gram-negative } \\
\text { Spirilliaceae rods } \\
\end{array}$ & $\begin{array}{l}\text { Width }=0.4-0.6 \\
\text { Length }=4-30\end{array}$ & $\begin{array}{l}\text { Found in sea water and } \\
\text { marine animals }\end{array}$ & Fluorescent pigment & chitin & N/A & $\begin{array}{l}\text { CRC Hand Book } \\
(1977)\end{array}$ \\
\hline $\begin{array}{l}\text { Photobacterium } \\
\text { phosphoreum }\end{array}$ & $\begin{array}{l}\text { Gram-negative } \\
\text { Vibrionaceae rods }\end{array}$ & $\begin{array}{l}\text { Width }=0.4-1.0 \\
\text { Length }=1.0-2.5\end{array}$ & $\begin{array}{l}\text { Found in sea water and in } \\
\text { marine animals. } \\
\text { Anaerobic. pH } 6.0-9.0 \\
(\text { opt }=7.0), 20-30^{\circ} \mathrm{C}\end{array}$ & Luminescent & chitin & $\begin{array}{l}\text { U. S. Dep. of Agri. } \\
\text { and Envi. Toxi. } \\
\text { Res., Oxford, MS }\end{array}$ & Benton et al. (1995) \\
\hline Proteus vulgaris & $\begin{array}{l}\text { Gram-negative } \\
\text { Enterobacteriaceae } \\
\text { rods }\end{array}$ & $\begin{array}{l}\text { Width }=0.5-1.0 \\
\text { Length }=1.0-3.0\end{array}$ & $\begin{array}{l}\text { Found in intestinal and } \\
\text { urinary tract. Facultatively } \\
\text { Anaerobic } 37^{\circ} \mathrm{C} \text {. }\end{array}$ & $\begin{array}{l}\text { No Fluorescent } \\
\text { pigment }\end{array}$ & proteins, aminopolysaccharides & $\begin{array}{l}\text { Gulf Oil Corp, and } \\
\text { U. of Houston, } \\
\text { Houston, TX }\end{array}$ & Kalish et al. (1964) \\
\hline $\begin{array}{l}\text { Pseudomonas } \\
\text { aeruginosa }\end{array}$ & $\begin{array}{l}\text { Gram-negative } \\
\text { Pseudomonad- } \\
\text { aceae tods }\end{array}$ & $\begin{array}{l}\text { Width }=0.5-0.8 \\
\text { Length }=1.5-3.0\end{array}$ & $\begin{array}{l}\text { Moist environments, even } \\
\text { in distilled water. Aerobic. } \\
10-42^{\circ} \mathrm{C} \text { (opt } 35^{\circ} \mathrm{C} \text { ) }\end{array}$ & Fluorescent pigment & $\begin{array}{l}\text { dichloromethane, diesel fuels, } \\
\text { crude oil, creosote, o-diphenol, } \\
\text { 2,4, 6-trichlorophenol, toluene, } \\
\text { hexadecane, heptadecane, } \\
\text { octadecane, nonadacane }\end{array}$ & $\begin{array}{l}\text { Gulf Oil Corp. } \\
\text { Houston, TX }\end{array}$ & Kalisb et al. (1964) \\
\hline $\begin{array}{l}\text { Pseudomonas } \\
\text { aureofacien }\end{array}$ & $\begin{array}{l}\text { Gram-negative } \\
\text { Pseudomonad- } \\
\text { aceae rods }\end{array}$ & $\begin{array}{l}\text { Width }=0.7-0.8 \\
\text { Length }=1.9-2.8\end{array}$ & Aerobic, $30^{\circ} \mathrm{C}$ & Fluorescent pigment & $\begin{array}{l}\text { Petroleum hydrocarbons, diesel } \\
\text { fuels, o-diphenol, arabinose, } \\
\text { saccharate, verlerate, phenyl } \\
\text { acetate }\end{array}$ & N/A & $\begin{array}{l}\text { CRC Hand Book } \\
(1977)\end{array}$ \\
\hline $\begin{array}{l}\text { Pseudomonas } \\
\text { cepacia }\end{array}$ & $\begin{array}{l}\text { Gram-negative } \\
\text { Pseudomonad- } \\
\text { aceae rods }\end{array}$ & $\begin{array}{l}\text { Width }=0.8-1.0 \\
\text { Length }=1.6-3.2\end{array}$ & Aerobic, $30-35^{\circ} \mathrm{C}$ & $\begin{array}{l}\text { No fluorescent } \\
\text { pigment }\end{array}$ & $\begin{array}{l}\text { 2, 4,6-trichlorphenol, } 2,4-, 2,6- \\
\text { and 3,4-dichlorophenol, herbi- } \\
\text { cide, } 2,3 \text {-butylene glycol, m- } \\
\text { hydro benzoate, aliphatic acid } \\
\mathrm{C}_{2}-\mathrm{C}_{10}\end{array}$ & $\begin{array}{l}\text { Universite Rene } \\
\text { decartes, } \\
\text { Paris, France }\end{array}$ & Tomasi et al. (1995) \\
\hline $\begin{array}{l}\text { Pseudomonas } \\
\text { chloraphis }\end{array}$ & $\begin{array}{l}\text { Gram-negative } \\
\text { Pseudomonad- } \\
\text { aceae rods }\end{array}$ & $\begin{array}{l}\text { Width }=0.7-0.8 \\
\text { Length }=1.5-3.6\end{array}$ & Aerobic, $30^{\circ} \mathrm{C}$ & Fluorescent pigment & $\begin{array}{l}\text { o-diphenol, saccharates, valerate, } \\
\text { ethanol }\end{array}$ & $\begin{array}{l}\text { U. Rene decertes, } \\
\text { Paris, France }\end{array}$ & Tomasi et al. (1995) \\
\hline $\begin{array}{l}\text { Pseudomonas } \\
\text { cichorii }\end{array}$ & $\begin{array}{l}\text { Gram-negative } \\
\text { Pseudomonad- } \\
\text { aceae rods }\end{array}$ & $\begin{array}{l}\text { Width }=0.8-1.0 \\
\text { Length }=0.2-3.5\end{array}$ & Aerobic, $30^{\circ} \mathrm{C}$ & Fluorescent pigment & $\begin{array}{l}\text { o-diphenol, glucose, succinate, } \\
\text { L-alanine, DL-lactate, } \\
\text { DL-arginine } \\
\end{array}$ & $\begin{array}{l}\text { U. Rene dacertes, } \\
\text { Paris, France }\end{array}$ & Tomasi et al. (1995) \\
\hline $\begin{array}{l}\text { Pseudomonas } \\
\text { Fluorecens }\end{array}$ & $\begin{array}{l}\text { Gram-negative } \\
\text { Pseudomonad- } \\
\text { aceae rods }\end{array}$ & $\begin{array}{l}\text { Width }=0.7-0.8 \\
\text { Length }=2.3-2.8\end{array}$ & $\begin{array}{l}\text { Found in soil and water. } \\
\text { Aerobic to facultive } \\
\text { anaerobic, } 25-30^{\circ} \mathrm{C}\end{array}$ & Fluorescent pigment & $\begin{array}{l}\text { naphthalene, chromium (VD), } \\
\text { o-diphenol }\end{array}$ & $\begin{array}{l}\text { Agri. U. of } \\
\text { Norway, } \\
\text { Olso, Norway }\end{array}$ & Birkland et al. (1985) \\
\hline $\begin{array}{l}\text { Pseudomonas } \\
\text { paucimobilis }\end{array}$ & $\begin{array}{l}\text { Gram-negative } \\
\text { Pseudomonad- } \\
\text { aceae rods }\end{array}$ & $\begin{array}{l}\text { Width }=0.5-1.5 \\
\text { Length }=0.7-1.4\end{array}$ & $\begin{array}{l}\text { Found in soils } \\
\text { Aerobic }\end{array}$ & $\begin{array}{l}\text { Non fluorescent } \\
\text { yellow pigment }\end{array}$ & $\begin{array}{l}\text { polycylic aromatichydrocarbons, } \\
\text { fluoranthreae, anthracene, benzo } \\
\text { [b] fluorene, naphthalene, } \\
\text { 1-methynaphthalene, } \\
\text { 2-methyl naphthalene }\end{array}$ & $\begin{array}{l}\text { U. S. E. P. A. } \\
\text { Guif Breeze, } \\
\text { Florida }\end{array}$ & Mueiler et al. (1990) \\
\hline $\begin{array}{l}\text { Pseudomonas } \\
\text { purida }\end{array}$ & $\begin{array}{l}\text { Gram-negative } \\
\text { Pseudomonad- } \\
\text { aceae rods }\end{array}$ & $\begin{array}{l}\text { Width }=0.7-1.1 \\
\text { Length }=2.0-4.0\end{array}$ & $\begin{array}{l}\text { Found in soil and water } \\
\text { Aerobic } \\
25-30^{\circ} \mathrm{C}\end{array}$ & Fluorescent pigment & $\begin{array}{l}\text { trichloroethene, naphthalene, } \\
\text { phenol, toluene, o-diphenol }\end{array}$ & $\begin{array}{l}\text { Cornell University } \\
\text { Ithica, NY }\end{array}$ & Madsen et al. (1982) \\
\hline $\begin{array}{l}\text { Pseudomonas } \\
\text { sepedonicum }\end{array}$ & $\begin{array}{l}\text { Gram-negative } \\
\text { Pseudomonad- } \\
\text { aceae rods }\end{array}$ & $\begin{array}{l}\text { Width }=0.5-1.0 \\
\text { Length }=1.5-4.0\end{array}$ & Aerobic & $\begin{array}{l}\text { No fluorescent } \\
\text { pigment }\end{array}$ & $\begin{array}{l}\text { chloro- \& methyl aromates } \\
\text { p-nitrophenol, o-diphenol }\end{array}$ & $\begin{array}{l}\text { Cornell University } \\
\text { Ithica, NY }\end{array}$ & Gannon et al. (1991) \\
\hline $\begin{array}{l}\text { Pseudomonas } \\
\text { syringae }\end{array}$ & $\begin{array}{l}\text { Gram-negative } \\
\text { Pseudomonad- } \\
\text { aceae rods }\end{array}$ & $\begin{array}{l}\text { Width }=0.7-1.2 \\
\text { Length }=1.5-3.0\end{array}$ & $\begin{array}{l}\text { Aerobic } \\
25-30^{\circ} \mathrm{C}\end{array}$ & Fluorescent pigment & $\begin{array}{l}\text { o-diphenol, carbohydrates, } \\
\text { organic \& amino acids, } \\
\text { succinate, L-alanine }\end{array}$ & $\mathrm{N} / \mathrm{A}$ & $\begin{array}{l}\text { Zinsser } \\
\text { Microbiology. (1992) }\end{array}$ \\
\hline $\begin{array}{l}\text { Salmonella } \\
\text { enteritidis }\end{array}$ & $\begin{array}{l}\text { Gram-negative } \\
\text { Enterobacteria- } \\
\text { ceace rods }\end{array}$ & $\begin{array}{l}\text { Width }=0.9-1.0 \\
\text { Length }=1.0-2.4\end{array}$ & $\begin{array}{l}\text { Found in man and animais. } \\
37^{\circ} \mathrm{C}\end{array}$ & $\begin{array}{l}\text { No Fluorescent } \\
\text { pigment }\end{array}$ & diesel fuel, crude oil & N/A & $\begin{array}{l}\text { Zinsser } \\
\text { Microbiology. (1992) }\end{array}$ \\
\hline $\begin{array}{l}\text { Salmonella } \\
\text { typhimurium }\end{array}$ & $\begin{array}{l}\text { Gram-negative } \\
\text { Enterobacteria- } \\
\text { ceace rods } \\
\end{array}$ & $\begin{array}{l}\text { Width }=0.9-1.0 \\
\text { Length }=1.0-2.4\end{array}$ & $\begin{array}{l}\text { Found in animais. } \\
37^{\circ} \mathrm{C}\end{array}$ & $\begin{array}{l}\text { No Fluorescent } \\
\text { pigment }\end{array}$ & $\begin{array}{l}\text { diesel fuel, crude oil } \\
\text { chlorophenol, trimethylamine } \\
\text { oxide }\end{array}$ & $\begin{array}{l}\text { U. of South } \\
\text { Alabama } \\
\text { Mobile, AL }\end{array}$ & Lin et al. (1995) \\
\hline $\begin{array}{l}\text { Shigella } \\
\text { lexneri }\end{array}$ & $\begin{array}{l}\text { Gram-negative } \\
\text { Enterobacteria- } \\
\text { ceace rods } \\
\end{array}$ & $\begin{array}{l}\text { Non-motile rods } \\
\text { not encapsulated }\end{array}$ & Found in animals & $\begin{array}{l}\text { No Fluorescent } \\
\text { pigment }\end{array}$ & $\begin{array}{l}\text { diesel fuel, crude oil, mannitol, } \\
\text { dulcitol }\end{array}$ & $\begin{array}{l}\text { U. of South } \\
\text { Alabama } \\
\text { Mobile, AL }\end{array}$ & Lin et al. (1995) \\
\hline $\begin{array}{l}\text { Staphlococcus } \\
\text { aureus }\end{array}$ & $\begin{array}{l}\text { Gram-positive } \\
\text { Staphlococcus } \\
\text { rods }\end{array}$ & $\begin{array}{l}\text { Width }=0.5 \\
\text { Length }=1.5\end{array}$ & $\begin{array}{l}\text { Found in human skin. } \\
\text { Anaerobic }\end{array}$ & $\begin{array}{l}\text { No Fluorescent } \\
\text { pigment }\end{array}$ & diesel fuel, crude oil, manitol & N/A & $\begin{array}{l}\text { CRC Hand Book } \\
(1977)\end{array}$ \\
\hline
\end{tabular}


Table II. Nonionic Surfactant Desorption of $\left[{ }^{14} \mathrm{C}\right]-P h e n a n t h r e n e$ from Coke Waste (Sanseverino et al. 1994)

\section{Dose (percent volume)}

\begin{tabular}{lllll} 
Surfactant & 0.02 & 0.2 & 0.5 & 1.0 \\
Alfonic 810-60 & 1.8 & 0.6 & -- & 19.3 \\
Novel II 1412-56 & 1.2 & 2.2 & $\ldots--$ & 30.7 \\
Tween 85 & 1.2 & 6.1 & --- & 31.1 \\
Brij 30/Brij 35 (1:1) & 2.3 & --- & 9.4 & 20.7 \\
Neodol 23-3/23-9 (3:1) & 1.9 & --- & 16.6 & 32.3 \\
\hline
\end{tabular}

Data are presented as percent $\left[{ }^{14} \mathrm{C}\right]$-Phenanthrene solubilized into the aqueous phase.

Table III. Plant Operating Parameters (Zacharias et al. 1995)

\begin{tabular}{lccccc}
\hline Parameters & Gas supply & $\begin{array}{c}\text { Delivery } \\
(\mathrm{l} / \mathrm{h})\end{array}$ & $\begin{array}{c}\text { Flow rate } \\
(\mathrm{m} / \mathrm{h})\end{array}$ & $\begin{array}{c}\text { Retention } \\
(\mathrm{h})\end{array}$ & Fixed Bed \\
\hline Plant 1 & $\mathrm{~N}_{2}$ & 5 & 0.283 & 6.4 & Soil/gravel \\
Plant 2 & $\mathrm{O}_{2}$ & 5 & 0.283 & 6.4 & Soil/gravel \\
Plant 3 & Air & 5 & 0.283 & 6.4 & Soil/gravel \\
Plant 4 & Air & 10 & 0.566 & 3.2 & Sand/gravel \\
\hline
\end{tabular}


Table IV. Microbial Degradation of Oil to $\mathrm{CO}_{2}$ (mg/100 gm Soil) (Ying et al 1989)

Soil with $15,000 \mathrm{ppm}$ Oil (nutrient/glucose supplemented)

$\begin{array}{lr}5 \% \text { moisture } & 6.9 \pm 0.3 \\ 10 \% \text { moisure } & 52.2 \pm 1.2 \\ 15 \% \text { moisture } & 56.4 \pm 0.6 \\ 20 \% \text { moisture } & 46.5 \pm 3.9\end{array}$

Soil with 35,000 ppm Oil (nutrient/glucose supplemented)

$\begin{array}{lr}5 \% \text { moisture } & 1.8 \pm 0.0 \\ 10 \% \text { moisture } & 19.2 \pm 1.2 \\ 15 \% \text { moisture } & 30.0 \pm 6.0 \\ 20 \% \text { moisture } & 28.8 \pm 5.4\end{array}$

Table V. Influence of Ionic Strength and $\mathrm{pH}$ on Collision Efficiency: Experimental Conditions and Results (Jewett et al. 1995)

\begin{tabular}{ccccc}
\hline Experiment & Ionic Strength $(\mathrm{M})$ & $\mathrm{pH}$ & $\mathrm{F}_{\mathrm{p}}$ & $\alpha$ \\
1 & 0.10 & 7 & $0.11( \pm 0.04, \mathrm{n}=14)$ & $0.18(0.16-0.22)$ \\
2 & 0.01 & 7 & $0.15( \pm 0.04, \mathrm{n}=4)$ & $0.17(0.15-0.20)$ \\
3 & 0.001 & 7 & $0.25( \pm 0.04, \mathrm{n}=4)$ & $0.12(0.11-0.14)$ \\
4 & 0.00001 & 7 & $0.52( \pm 0.04, \mathrm{n}=4)$ & $0.026(0.052-0.066)$ \\
5 & 0.10 & 5 & $0.13( \pm 0.04, \mathrm{n}=8)$ & $0.20(0.17-0.22)$ \\
6 & 0.10 & 6 & $0.08( \pm 0.03, \mathrm{n}=8)$ & $0.23(0.20-0.27)$ \\
\hline
\end{tabular}

$F_{p}$ is the mean fractional cell penetration, $95 \%$ confidence interval for $F_{p}$ and number of experiments conducted $(\mathrm{n})$ in parenthese.

Bacterial collision efficiency, $\alpha$, range of $\alpha$ 's for $95 \%$ confidence interval of $F_{p}$ in parentheses. 
Table VI. Critical Environmental Factors for Microbial Activity (Sims et al. 1990)

\section{Environmental Factor}

Soil Moisture

Oxygen

Redox potential

$\mathrm{pH}$

Nutrients

Temperature
Optimum Levels

$25-85 \%$ of water holding capacity; $-0.01 \mathrm{MPa}$

Aerobic metabolism: Greater than 0.2 $\mathrm{mg} / \mathrm{L}$ dissolved oxygen, minimum air-filled pore space of $10 \%$ by volume; Anaerobic metabolism: $\mathrm{O}_{2}$ concentration less than $1 \%$ by volume.

Aerobes and facultative anaerobes: greater than 50 millivolts;

Anaerobes: less than 50 millivolts .

5.5-8.6

(also suggested 6.5-8.5; Ritter, 1995)

Sufficient nitrogen, phosphorus, and other nutrients for microbial growth (Suggested C:N:P ratio of 120:10:1) (also suggested 300:15:1; Ritter, 1995)

$15-45^{\circ} \mathrm{C}$

(also suggested $27^{\circ} \mathrm{C}-35^{\circ} \mathrm{C}$; Ritter 1995) 


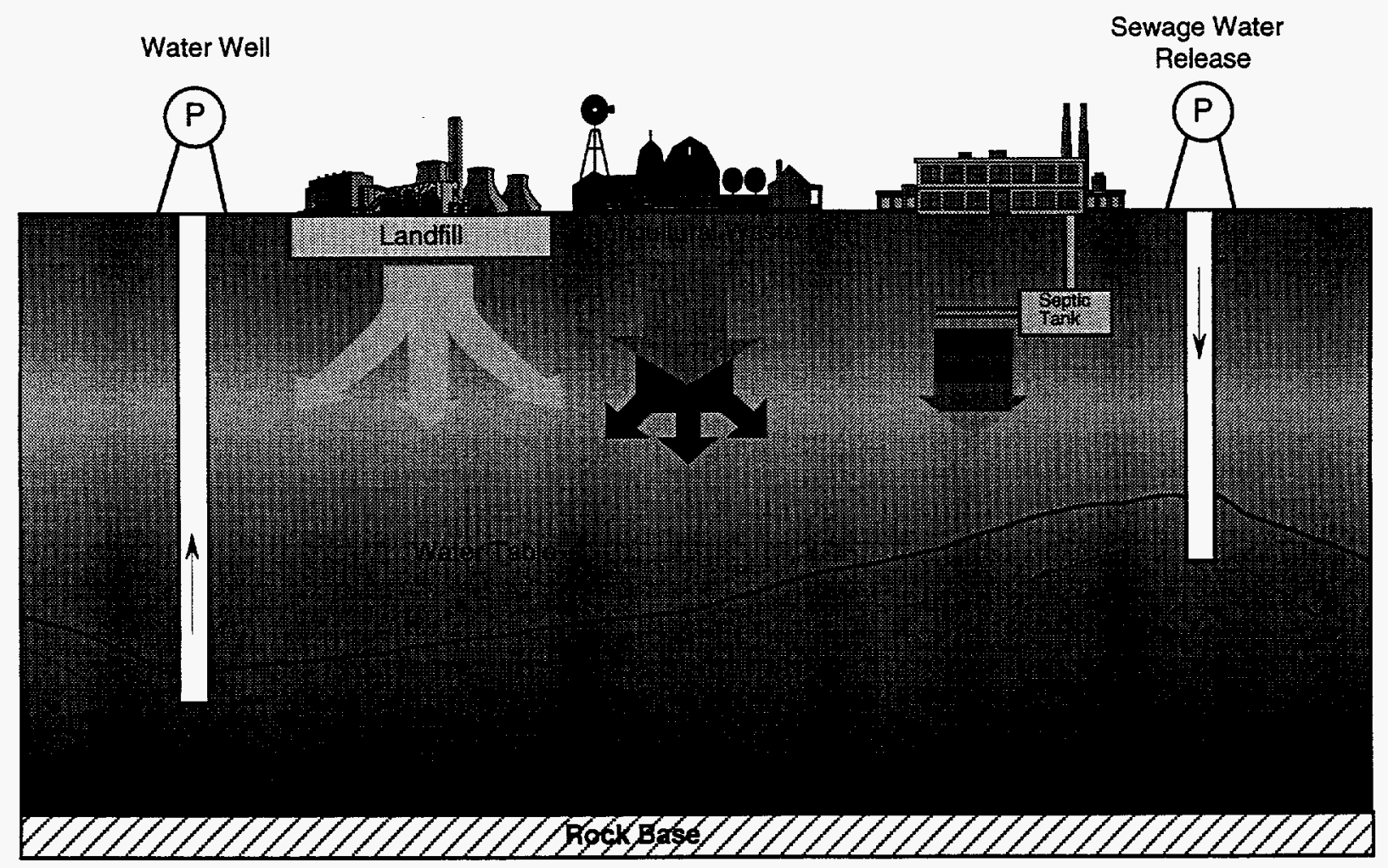

Figure 1. Source of contamination in ground water. 
Ground Surface

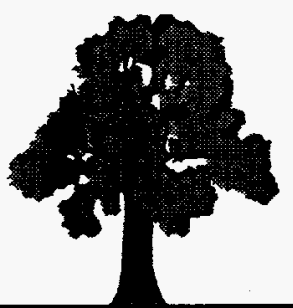

Unsaturated

(Vadose)

Zone

Satuarted

Zone

Figure 2. Various soil zones where contaminants penetrate. 


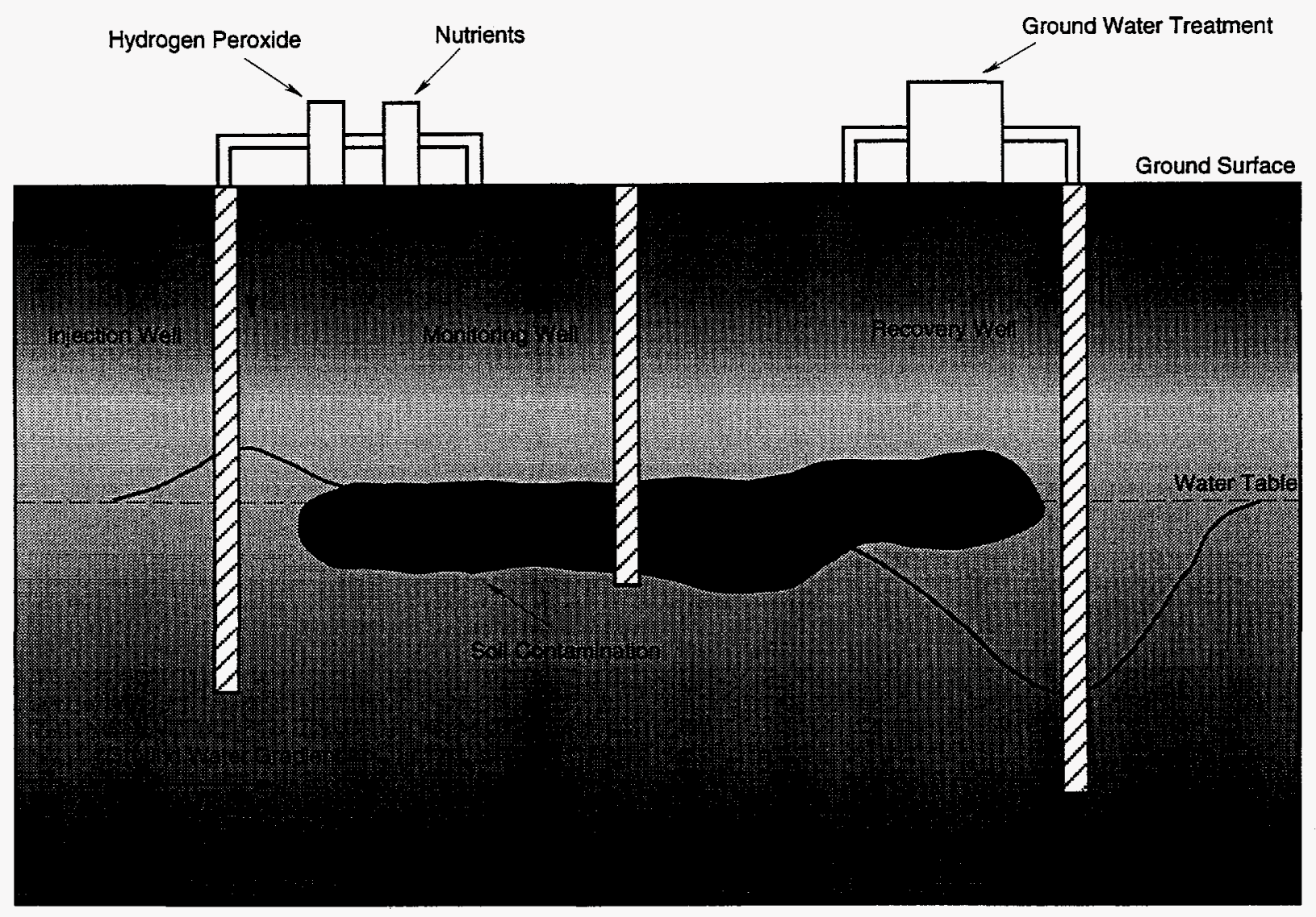

Figure 3. In-situ bioremediation of saturated and unsaturated zone. Recovered ground water is treated typically using an air stripper tower. It is amended with nutrients and is injected back in soil. Oxygen or hydrogen peroxide is supplied into the soil using the injection well. 
Ground Water System

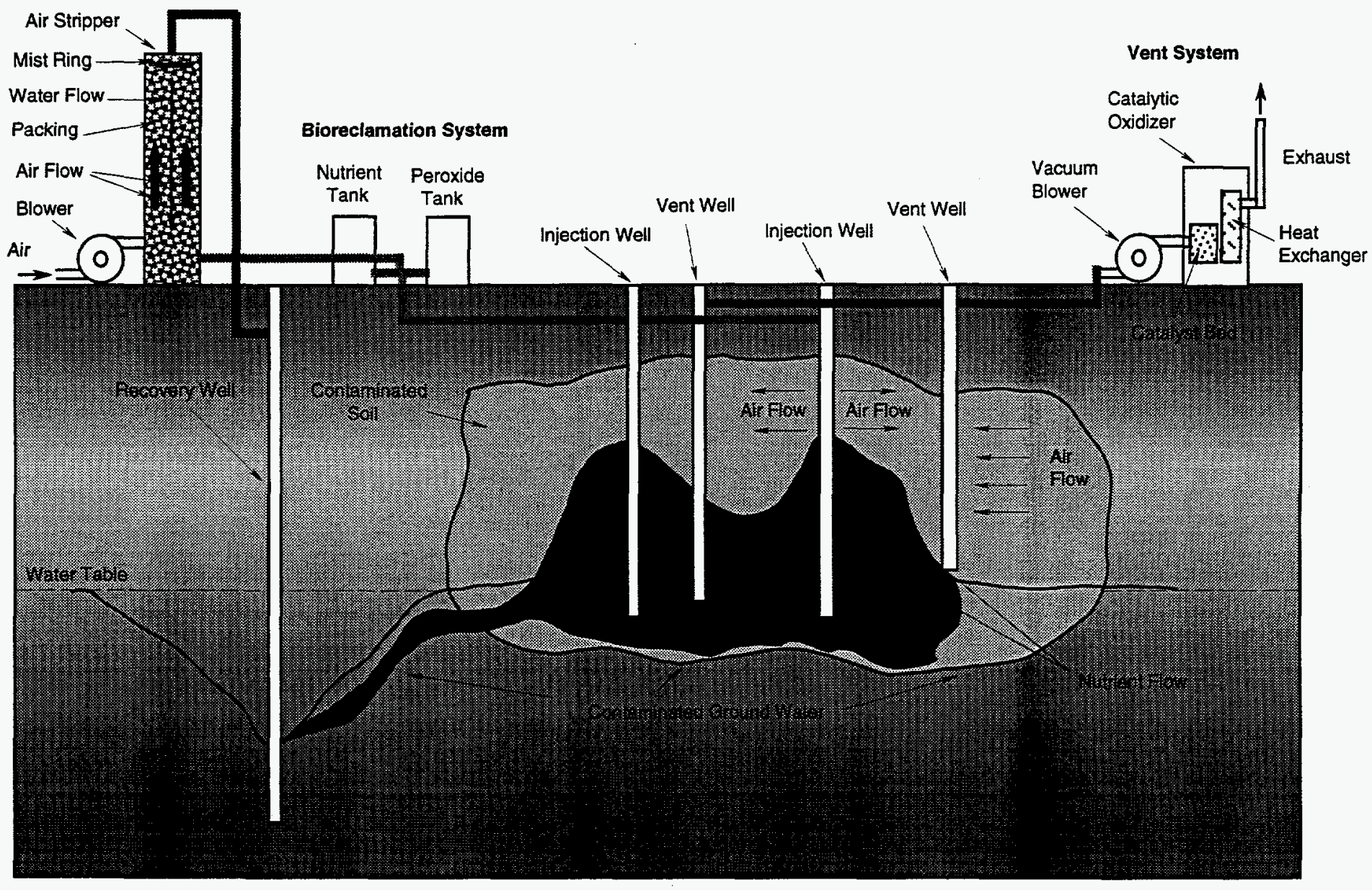

Figure 4. An integrated in-situ bioremediation system. 


\begin{tabular}{|c|c|}
\hline Aqueous Salt: & 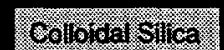 \\
\hline
\end{tabular}

Pyrogenendotoxil

1. Yeasteel:

Beach Sand

Woral on

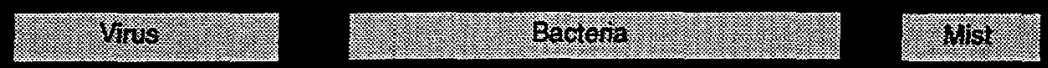

(n)

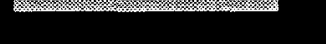
$\left(\frac{10}{10}\right.$ Asbestos:

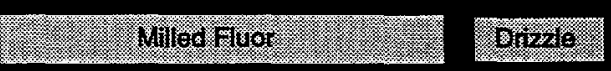

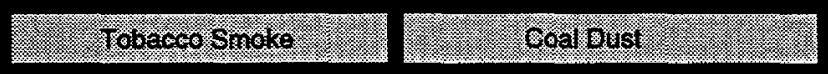

Sugar

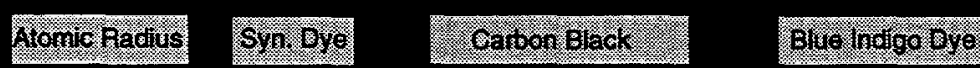

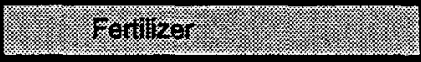

. Polon:

Figure 5. Comparison of bacteria size with size of some common materials. 

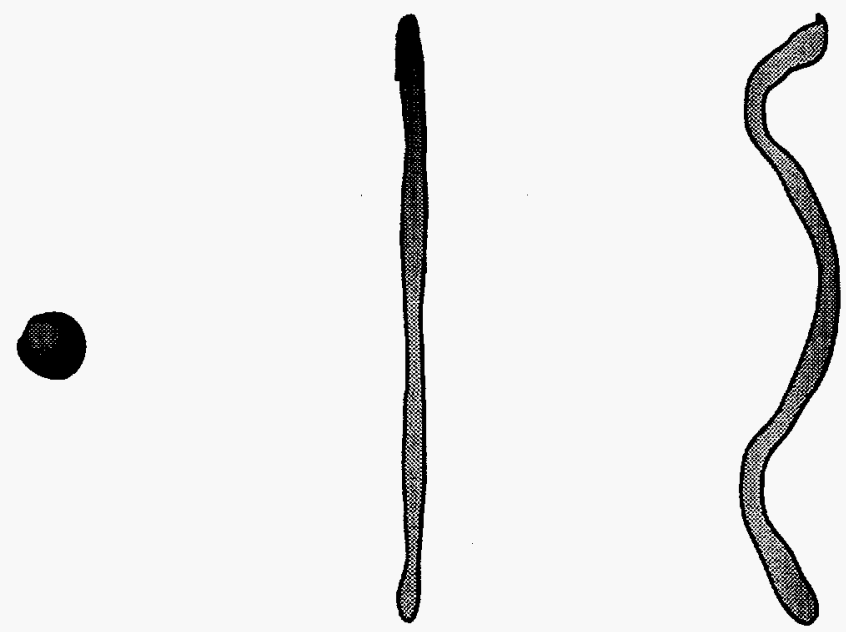

Round (coccus)

Rod-shaped (bacillus)

Spiral (spirillum)

Figure 6. Typical shapes of bacteria. 


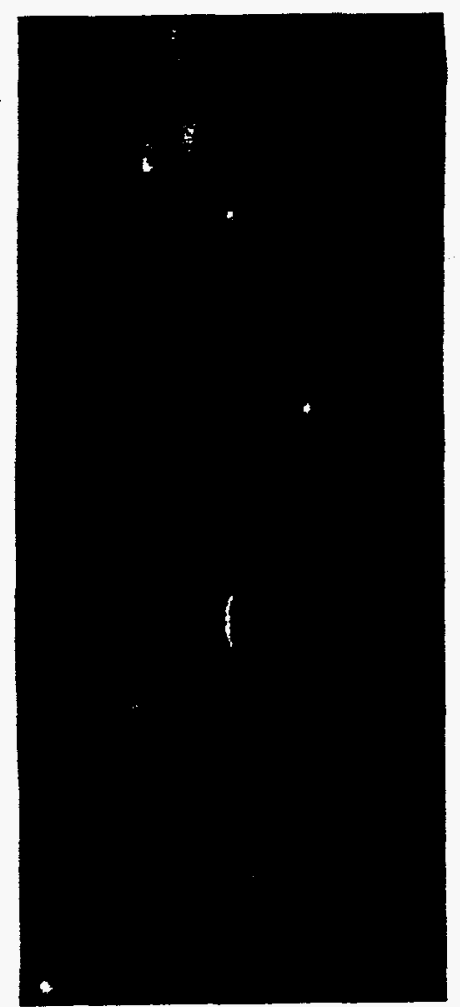

(a)

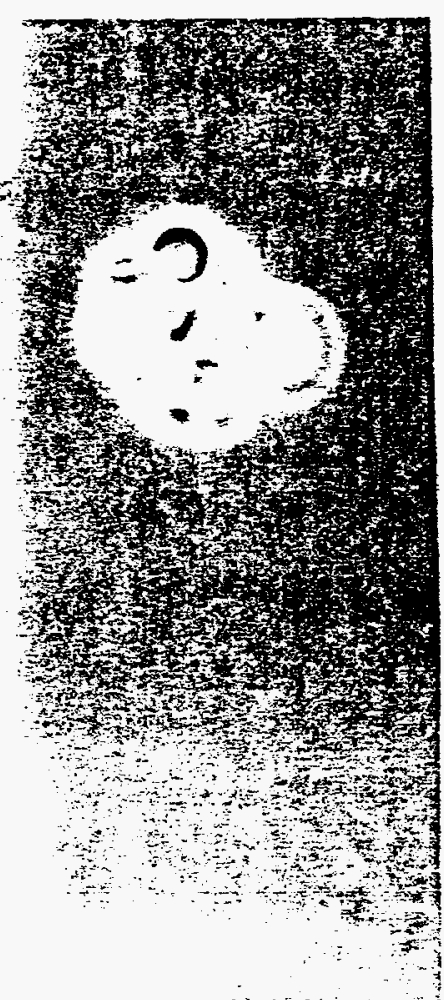

(b)

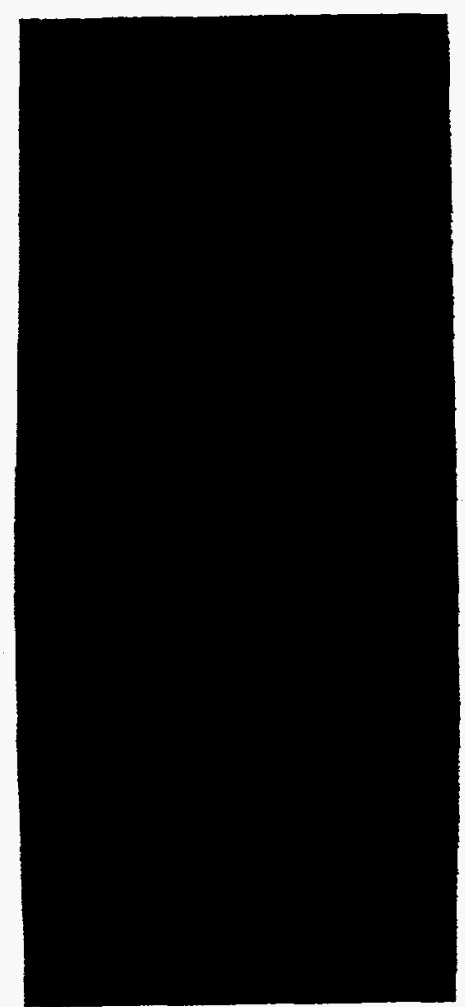

(c)

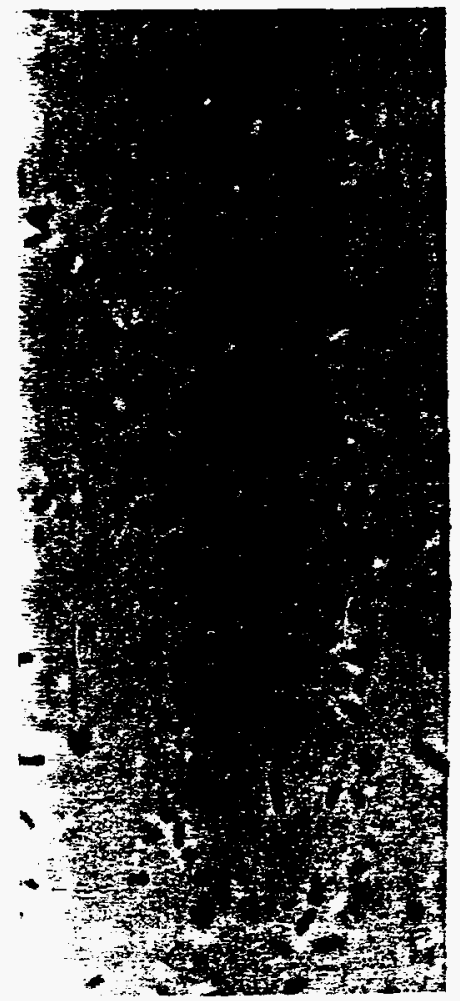

(d)

Figure 7. Fluorescent images of (a) sperms, (b) yeast cells, (c) coccus bacteria, and (d) bacillus bacteria. 


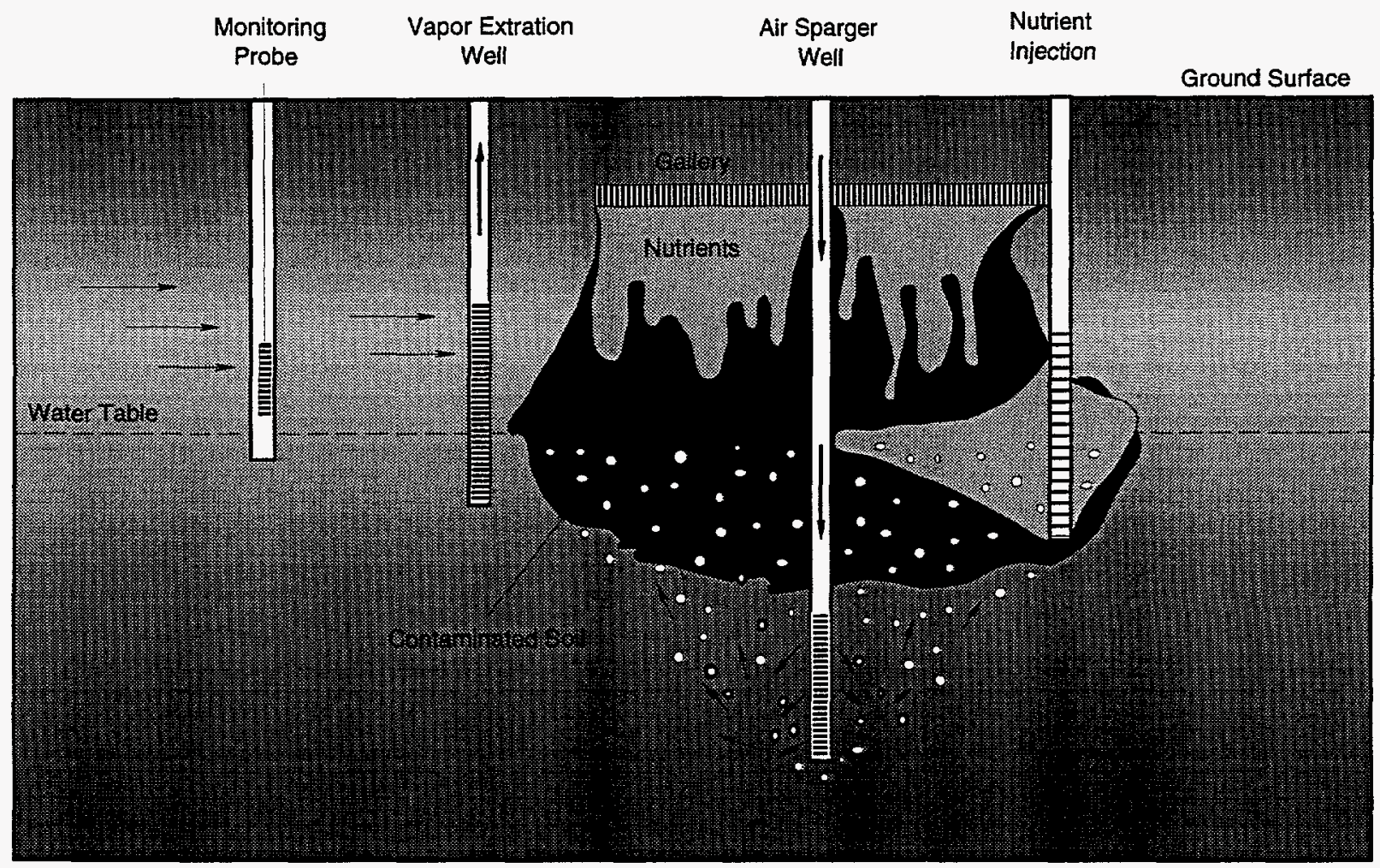

Figure 8. Conceptual view of air sparging system used in bioremediation processes. 


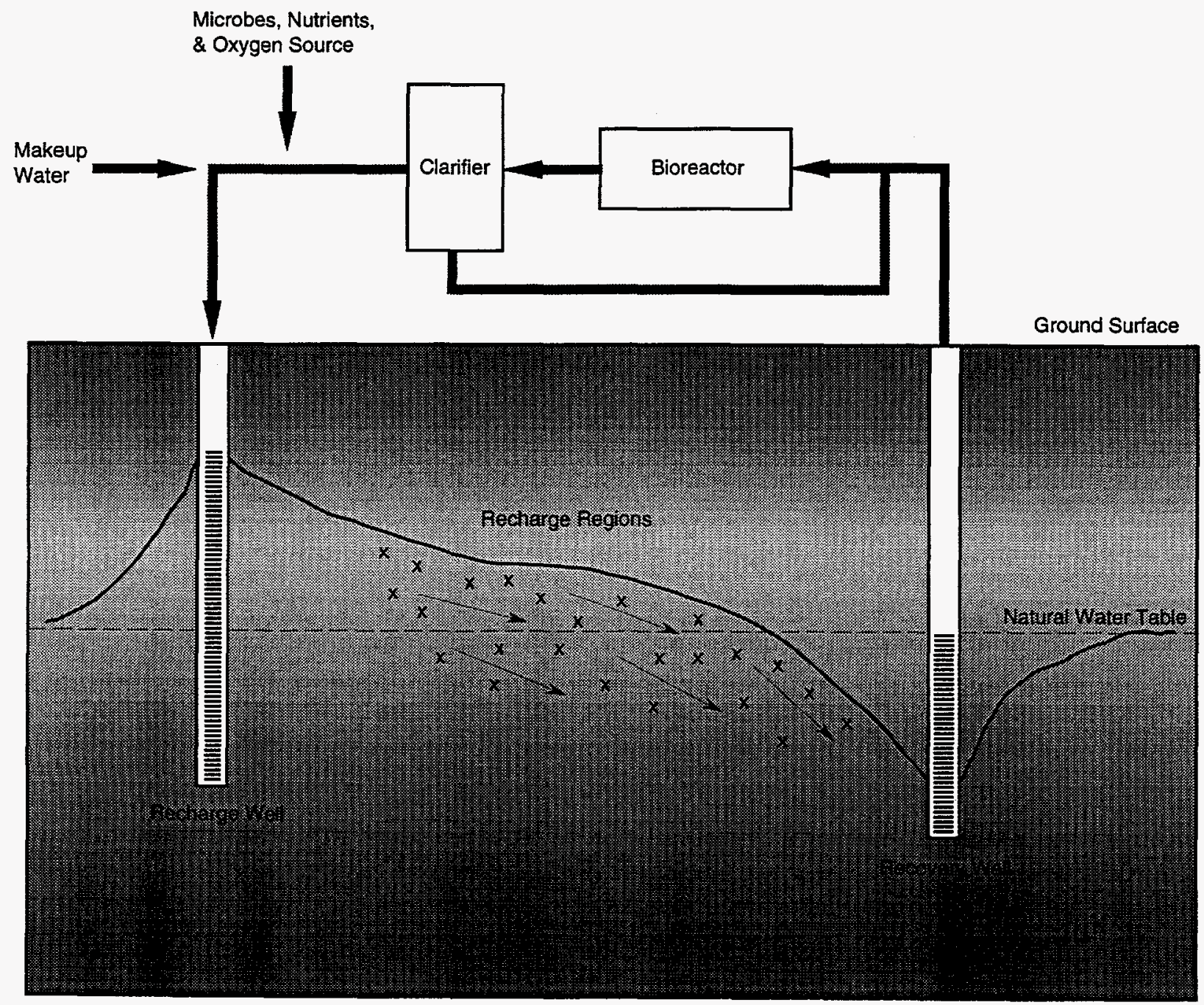

Figure 9. Bioaugmentation of Microbes in in-situ bioremediation. 

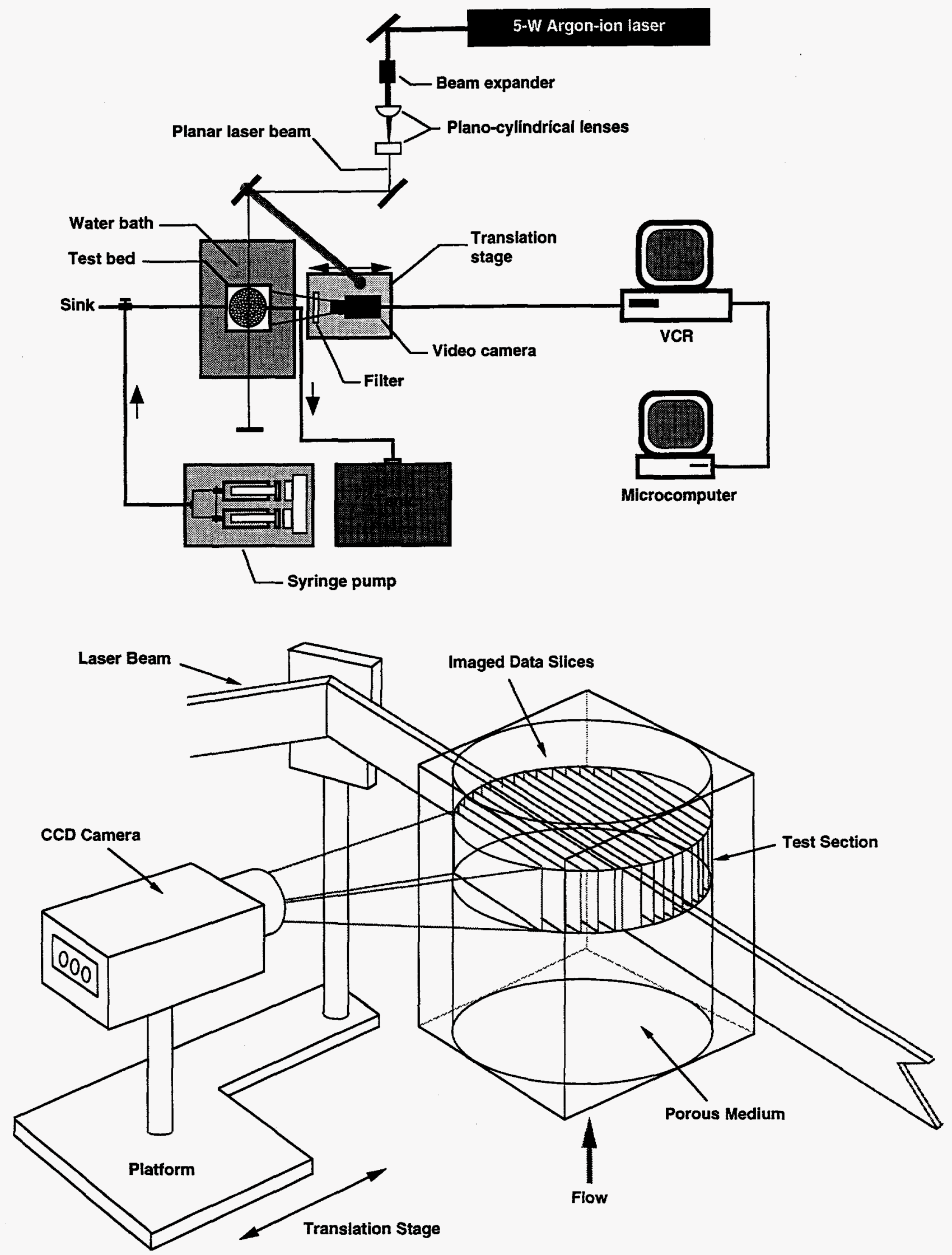

Figure 10. Measurement apparatus. Top view: Experimental setup; Bottom view: Imaging configuration. 


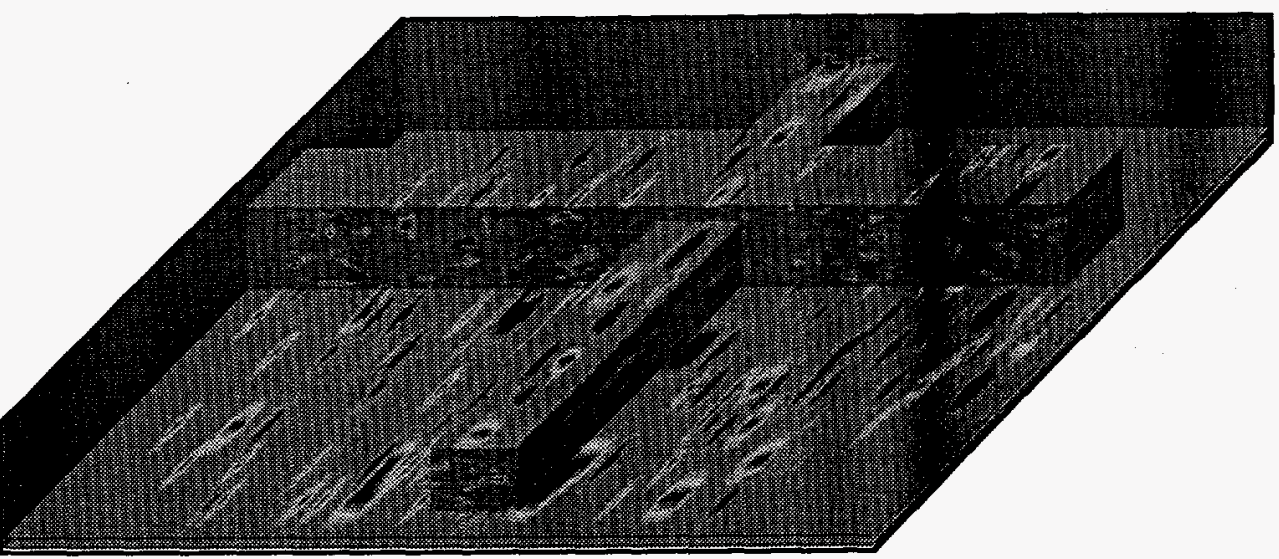

$-0.00250$

flux

0.00250

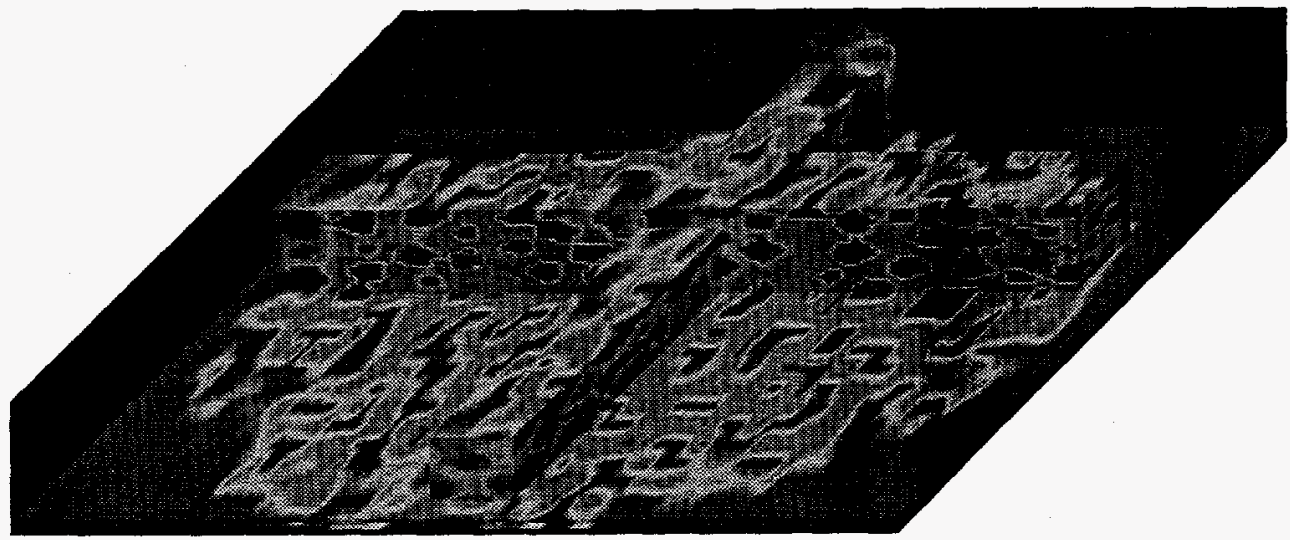

0.0

concentration

1.0
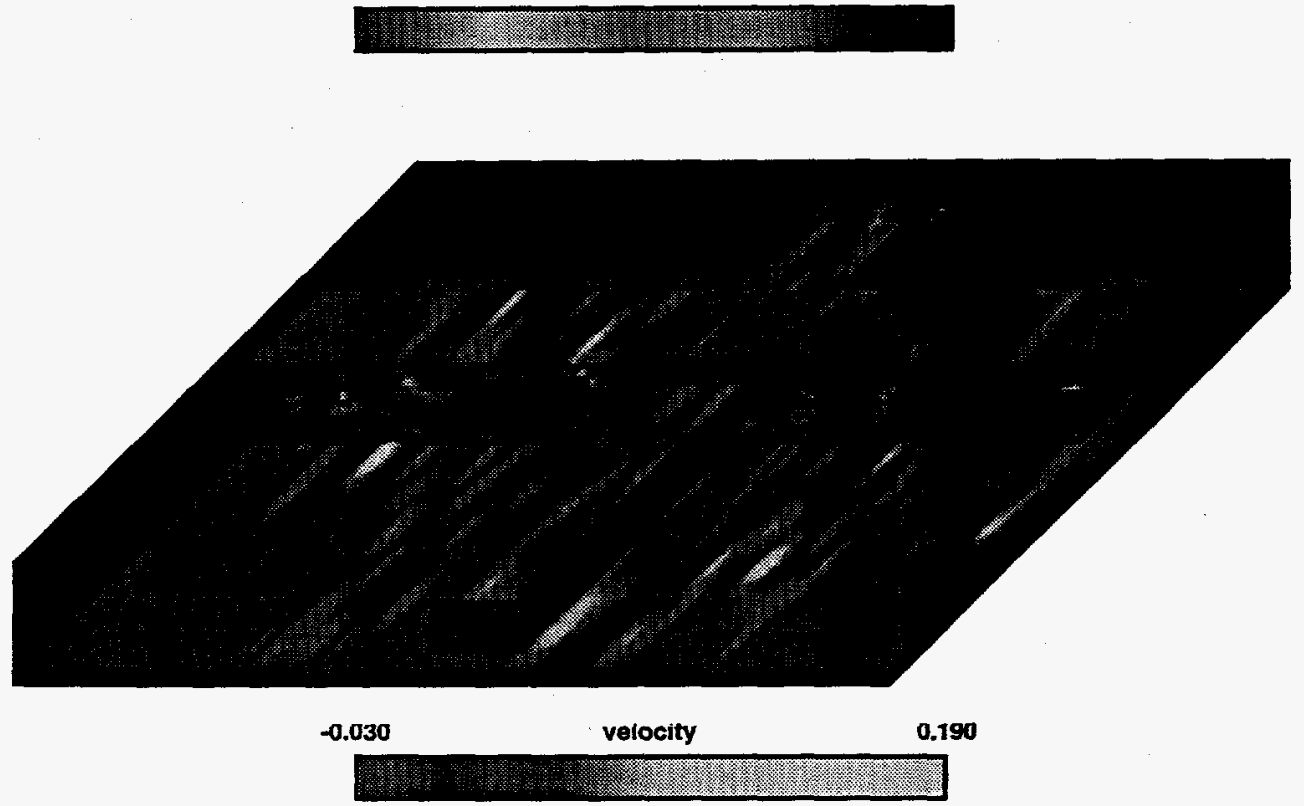

Figure 11. 3D plots of axial velocity deviations $(\mathrm{mm} / \mathrm{s})$, dimensionless concentration, and axial fluxes $(\mathrm{mm} / \mathrm{s})$ for $t=30$ minute. Here, flow direction is from bottom to top and concentrations \& fluxes are divided by saturated concentration values. 